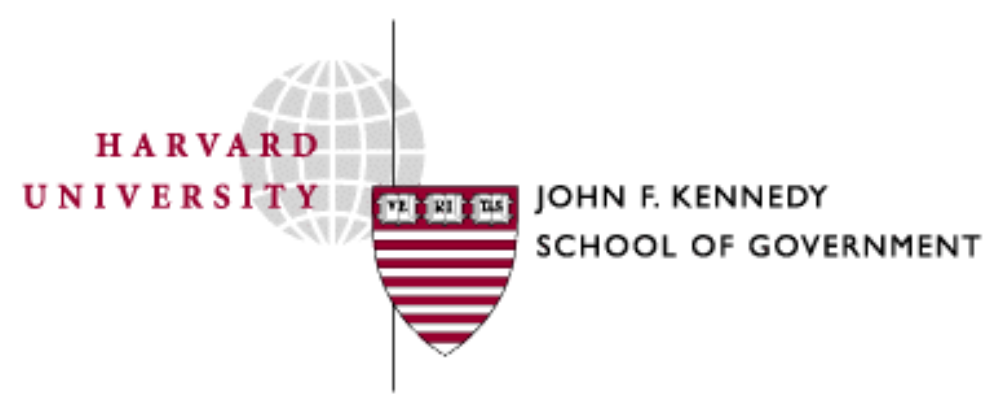

Faculty Research Working Papers Series

\title{
Securing Truth for Power: Informational Strategy and Regulatory Policy Making
}

\author{
Cary Coglianese, Richard Zeckhauser, and Edward Parson
}

May 2004

RWP04-021 belongs to the author(s). Papers may be downloaded for personal use only. 


\title{
Securing Truth for Power: Informational Strategy and Regulatory Policy Making*
}

\author{
Cary Coglianese \\ Irvine Visiting Professor of Law \\ Stanford Law School \\ Associate Professor of Public Policy \\ Chair of the Regulatory Policy Program \\ John F. Kennedy School of Government \\ Harvard University \\ www.ksg.harvard.edu/coglianese \\ Richard Zeckhauser \\ Frank Plumpton Ramsey Professor of Political Economy \\ John F. Kennedy School of Government \\ Harvard University \\ http://ksghome.harvard.edu/ .RZeckhauser.Academic.ksg/ \\ Edward Parson
Professor of Law
University of Michigan \\ http://cgi2.www.law.umich.edu/_FacultyBioPage/facultybiopagenew.asp?ID=271
}

\author{
Address Correspondence to: \\ Cary Coglianese \\ Stanford Law School \\ 559 Nathan Abbott Way \\ Stanford, California 94305-8610 \\ Stanford Telephone: (650) 723-4605 \\ Harvard Telephone: (617) 495-1402 \\ cary_coglianese@harvard.edu \\ ccoglianese@law.stanford.edu
}

\footnotetext{
* We are grateful to Peggy Chen for research assistance in connection with Part III, Miriam Avins for editorial assistance, and Richard Craswell, David Lazer, Jane Mansbridge, Jeff Strnad, Sam Walsh, and participants in seminars at the John F. Kennedy School of Government and the Stanford Law School for helpful comments on an earlier draft.
} 


\title{
Securing Truth for Power: Informational Strategy and Regulatory Policy Making
}

\begin{abstract}
$\underline{\text { Abstract }}$
Whether regulating mutual funds or chemical manufacturers, government's policy decisions depend on information possessed by industry. But it is not in any industry's interests to share information that will lead to costly regulations. So how do government regulators secure needed information from industry? Since information disclosed by any firm cannot be retrieved and can be used to regulate the entire sector, industry faces a collective action problem in maintaining silence. While collective silence is easy to maintain if all firms' interests are aligned, their payoffs for disclosure can vary due to heterogeneous effects of regulation and heterogeneous beliefs about the regulator's expected actions with or without any given information. The regulator's strategy is therefore to resist or break down industry's collective silence, either by (1) exploiting asymmetries in firms' interests in disclosure, or (2) selectively rewarding or punishing individual firms to create incentives for disclosure. Both of these strategies work best when pursued informally, in less visible ways, since other firms can be expected to inflict retribution on any squealer. Although informal relationships have been long deplored due to the risk of regulatory bias or capture, our analysis shows how they can be beneficial to government in playing the information game. This has important implications for regulatory procedure. Since total transparency would detract from government's ability to secure valuable information, administrative law needs to balance between the competing needs of transparency to prevent abuse and opacity to facilitate information exchange.
\end{abstract}




\title{
Securing Truth for Power: Informational Strategy and Regulatory Policy Making
}

\begin{abstract}
"The ... power that is involved here is the power to get information from those who best can give it and who are most interested in not doing so.”
\end{abstract}

United States v. Morton Salt Co., 338 U.S. 632, 642 (1950)

Information is the lifeblood of regulatory policy. The effective deployment of governmental power depends on information about conditions in the world, strategies for improving those conditions, and the consequences associated with deploying different strategies. ${ }^{1}$ Indeed, this need for information has led legislatures to create specialized committee structures, delegate policy authority to expert agencies, and develop administrative procedures that promote transparency and encourage analysis. ${ }^{2}$ Yet, legal scholars have paid little attention to how regulators gain the information they need for

\footnotetext{
${ }^{1}$ As Justice Breyer has written, “[t]he central problem of the standard-setting process and the most pressing task facing many agencies is gathering the information needed to write a sensible standard.” STEPHEN BReyer, Regulation and its Reform (1982). See generally Aaron WildaVsky, Speaking TRUTH to Power: The ART AND Craft of Policy ANALysis (1987).

${ }^{2}$ Keith Krehbiel, Information And Legislative Organization 4-6 (1991); Rui J.P. de Figueiredo, Jr., Pablo T. Spiller, \& Santiago Urbiztondo, An Informational Perspective on Administrative Procedures, 15 J. L. ECON. \& ORG. 283 (1999).
} 
making and implementing regulatory policy. ${ }^{3}$ While many information-gathering efforts by regulatory agencies look more or less like conventional scientific analysis (as when an environmental agency studies how pollutants travel through groundwater or a public health agency conducts epidemiological research), much needed information will not emerge from policy-relevant scientific research. ${ }^{4}$ In particular, regulators need information about the operations of private business enterprises. Such information enables regulators to understand the scope and cause of regulatory problems, and to craft effective solutions to them. ${ }^{5}$

Government regulators are usually poorly positioned to gather information about business operations, or at least to gather it cheaply. Often, the best source of information about the risks of products, the behavior of individuals and firms, the costs of remediation or mitigation, or the feasibility of different technologies will be the very firms that the

\footnotetext{
${ }^{3}$ Legal scholars have, of course, recognized that government officials need information. See, e.g., Breyer, supra note 1; Jerry L. Mashaw et AL., Administrative LAW: The AmeriCAn Public LaW System 5th ed (2003). (observing that “[s]ound decision making obviously requires good information”); Edward Rubin, It's Time to Make the Administrative Procedure Act Administrative, 89 CORNELL L. REv. 95 (2003) (acknowledging that "effective regulation demands large quantities of information”). However, they have yet to analyze the strategic considerations regulators face in obtaining that information through different means.

${ }^{4}$ For discussion of the role of science, science policy research, and science advisors in government decision making, see Sheila Jasanoff, The Fifth Branch: Science AdVISORS As Policymakers (1990).

${ }^{5}$ See infra Part I.A.
} 
government agency regulates. ${ }^{6}$ While these firms have an incentive to share favorable, self-serving information, regulators also need accurate information that private firms do not want to disclose. How does a regulator learn about and acquire information from parties who may suffer if they provide it?

In this article, we analyze regulators' gathering of information from firms as a strategic game. In Part I, we discuss the types of information that firms possess and regulators need. We then analyze the payoffs for regulated firms in keeping this information to themselves, arguing that silence by firms within an industry resembles the well-known problem of collective action. ${ }^{7}$ In Parts II and III, we discuss the strategies and tactics available to regulators to penetrate a regulated industry's silence and gather information needed to develop effective regulation. Although regulators cannot typically offer explicit side payments to firms to induce them to release information, they can deploy a variety of mechanisms to try to gather information from those whom the agency will target for regulation. Indeed, selective forms of what might be considered "regulatory capture" by individual firms may well be desirable from the standpoint of the

\footnotetext{
${ }^{6}$ Cary Coglianese, Litigating within Relationships: Disputes and Disturbance in the Regulatory Process, 30 L. \& SoC’Y. REV. 735, 749-750 (1996) (“[A]gency staff members depend heavily on outside groups for information. Effective regulation of an industry depends...on knowledge of how that industry works. Agency staff members routinely turn to organizations in the regulated community to provide this information.”).

${ }^{7}$ Edward Parson, Richard Zeckhauser, \& Cary Coglianese, Collective Silence and Individual Voice: The Logic of Information Games, in JAC HeCKelman \& Dennis CoATES, EDS., COlLECTIVE CHOICE: Essays IN HONOR OF MANCUR OLSON (2003).
} 
public interest in some cases, if in the process firms cede information that permits regulators to craft more effective and efficient regulatory policies. ${ }^{8}$

In Part IV, we consider the relative virtues of the strategies and tactics discussed in Parts II and III and theorize about conditions under which each will be appropriate. Finally, we discuss the tensions between regulators' need to gather information from industry and the kinds of administrative procedures that have arisen over the past several decades to provide legislators and others an opportunity to oversee the work of government regulators. Many administrative procedures promote transparency in government decision making almost as if it were an unalloyed good. Yet while transparency serves important goals, it also inhibits some beneficial government activities. We argue that regulators' need to secure information from those they regulate provides a reason for preserving some degree of opacity in some contexts in an otherwise transparent and accountable regulatory process.

\section{Industry Information and Regulatory Decision Making}

The existence of information asymmetries between producers and consumers is widely accepted as justifying certain kinds of regulatory interventions in the marketplace, including regulation requiring firms to disclose information. ${ }^{9}$ Asymmetric information

\footnotetext{
${ }^{8}$ See infra notes 98-115, 167-172 and accompanying text.

${ }^{9}$ Stephen Breyer, Regulation And Its Reform (1982); CAss R. Sunstein, Reconceiving the REGULATORY STATE (1989). The use of information disclosure as a regulatory strategy has received considerable attention. MARY GRAHAm, Democracy by Disclosure: The RiSE OF TeChNOPOPUlism
} 
also lies at the core of the principal-agent theory that has become central to the study of bureaucratic decision making. ${ }^{10}$ Positive analyses of regulatory policy making have focused on the strategies that legislators -- and other governmental overseers of administrative agencies -- use to overcome their information disadvantages vis-à-vis regulatory officials. ${ }^{11}$ Yet while the general problem of asymmetric information

(2002); Bradley C. Karkkainen, Information as Environmental Regulation: TRI and Performance Benchmarking, Precursor to a New Paradigm?, 89 GeORGETOWN L.J. 257 (2001); Paul R. Kleindorfer \& Eric W. Orts, Informational Regulation of Environmental Risks, 18 RISK ANALYSIS 155 (1998); Mary L. Lyndon, Information Economics and Chemical Toxicity: Designing Laws to Produce and Use Data, 87 MiCH. L. REV. 1795 (1989); Cass R. Sunstein, Informational Regulation and Informational Standing: Akins and Beyond, 147 U. PENN. L. Rev. 613 (1999).

${ }^{10}$ David Epstein \& Sharyn O’Halloran, Delegating Powers: A Transaction Cost Politics Approach to Policy Making Under Separate Powers (1999); Eric Posner, Controlling Agencies with Cost-Benefit Analysis: A Positive Political Theory Perspective, 68 UnIV. CHI. L. REv. 1137 (2001). The regulator (or administrative agency) is typically treated as the agent, while the legislature or executive is treated as a principal. For a discussion of principal-agent theory, see JOHN W. PRATT \& RICHARD J. Zeckhauser, eds., Principals And Agents: The Structure OF Business (1985).

${ }^{11}$ Murray J. Horn \& Kenneth A. Shepsle, Administrative Process and Organizational Form as Legislative Responses to Agency Costs, 75 VIRG. L. Rev. 499 (1989); Matthew McCubbins, Roger Noll, \& Barry Weingast, Administrative Procedures as Instruments of Political Control, 3 J. L., ECON., \& ORGAN. 243 (1987); Barry R. Weingast \& Mark J. Moran, Bureaucratic Discretion or Congressional Control? Regulatory Policymaking by the Federal Trade Commission, 91 J. PoL. ECON. 765 (1983). 
dominates the contemporary study of regulation, the asymmetries between regulators and those they regulate has escaped sustained attention. ${ }^{12}$

12 The existence of information asymmetries between regulators and firms has certainly been recognized. See, e.g., Paul L. Joskow and Richard Schmalensee, Incentive Regulation for Electric Utilities, 4 YALE J. ON REG. 1, 18 (1986) (noting that "the regulator's information is assumed to be inferior to that of the utility's management" and that "the assumption of asymmetric information is quite plausible"); Glenn Blackmon and Richard Zeckhauser, Fragile Commitments and the Regulatory Process, 9 YALE J. ON REG. 73, 104 (1992) (noting “the principal-agent relationship between the regulator and firm” and the firm's “advantage of superior information”); Barton H. Thompson, Jr., People or Prairie Chickens: The Uncertain Search for Optimal Biodiversity, 51 STAN. L. REV. 1127 (1999) (noting that regulators have a difficult time assessing the costs of regulatory options "because that information is generally in the hands of the regulated community, which has an incentive to overstate those costs"). However, virtually no attention has been given to the strategies regulators can use to overcome their informational disadvantage and the implications of this problem for the design of administrative law. In the relevant legal literature, we find only two extended analytical treatments of the information asymmetry between regulators and regulated entities. See Jason Scott Johnston, A Game Theoretic Analysis of Alternative Institutions for Regulatory Cost-Benefit Analysis, 150 U. PENN. L. REV. 1343 (2002) (providing a game theoretic analysis of information provision under different statutory requirements about benefit-cost analysis); Tracy Lewis and Michel Poitevin, Disclosure of Information in Regulatory Proceedings, 13 J.L. Econ. \& ORG. 50 (1997) (analyzing the effect on information provision and decision making of different evidentiary standards in regulatory proceedings). This work, like ours, recognizes the information asymmetries in making regulatory policy. However, it differs in important respects. For example, Johnston focuses on information asymmetries with respect to compliance costs only, whereas we recognize asymmetries in information about benefits as well. Lewis and Poitevin consider only the context where a regulator must review an application or petition from a regulated entity, while we analyze that context as but one of many institutional arrangements for gathering information. More importantly, unlike these studies, we tend to view the strategic problem from 
In this first Part we consider the nature and degree of regulators' informational dependence on those they regulate. We begin by explaining the importance of information in regulatory decision making, and then explain why industry usually disproportionately possesses the information needed to craft good regulatory policy. Most importantly, we show why an industry often has a collective interest in keeping to itself some or all of the information government decision makers need.

\section{A. Regulators’ Need for Information}

Government regulators face the challenge of breaking industry silence by securing information from those whose immediate interests would oppose its release. Regulators rely on information to tailor policies that will achieve their goals, such as reducing risks. They also need information for strategic reasons, such as to anticipate reactions by regulated entities and to persuade other political or legal actors that their decisions are appropriate.

Government regulation is generally required to correct for three main types of market failures: ${ }^{13}$ lack of competition (as in cases of monopoly); ${ }^{14}$ externalities (the failure of

the perspective of the regulator, identifying strategies for government to use to play the informational game embedded within regulatory policy making.

${ }^{13}$ Competitive markets prove highly successful for producing and allocating society's resources. However, the conditions for socially optimal market transactions do not always obtain. For an overview of the role and limits of the market, see EDITH StOKey \& Richard ZeCKHAUSER, A PRIMER FOR POLICY ANALYSIS 291-308 (1978). For recent discussion of market failures, see Office of Management and 
market prices to incorporate all the costs to society of a particular form of economic behavior); ${ }^{15}$ and a lack of full information about products and services (for prices therefore cannot reflect the true preferences of the parties). ${ }^{16}$ For each of these three

Budget, Economic Analysis of Federal Regulations Under Executive Order 12866 (Jan. 11, 1996), available at http://www.whitehouse.gov/omb/inforeg/riaguide.html (directing analysts to identify a “significant market failure” justifying each proposed regulation); Office of Management and Budget, Office of Information and Regulatory Affairs, A Report to the President on the Third Anniversary of Executive Order 12866 (Dec. 1996), available at http://www.whitehouse.gov/omb/inforeg/riaguide.html; Office of Management and Budget, Office of Information and Regulatory Affairs, Guidelines to Standardize Measures of Costs and Benefits and the Format of Accounting Statements (2000), available at http://www.whitehouse.gov/omb/ memoranda/m00-08.pdf. But see Richard O. Zerbe, Jr., \& Howard E. McCurdy, The Failure of Market Failure, 18 J. Pol. ANAL. \& MGT. 558 (1999) (arguing that a superficial focus on market failure can lead analysts to overlook the underlying causes of regulatory problems and that attention to transaction costs offers a better approach).

${ }^{14}$ Concentration of market power, whether through predatory behavior or a so-called "natural monopoly," enables firms to obtain rents by reducing supply below the levels that would arise in a fully competitive marketplace. David L. Weimer \& AidAn R. Vining, Policy Analysis: ConceptS And PRACtice (3d ed. 1998). Market power provides the justification for antitrust law and certain kinds of utility regulation.

${ }^{15}$ Id. Although manufacturing firms' count their private costs, such as capital, labor, and other inputs, they will not count the costs that pollution from their factories impose on neighboring communities. Environmental regulation responds to this type of market failure, seeking to alter firms' behavior in ways that reduce negative externalities.

${ }^{16}$ Id. Usually sellers will know more about the efficacy and safety of their products than will buyers. In such cases, government regulation may be needed to overcome the information asymmetries between consumers and sellers. Labeling and product testing requirements fall into this category. See also supra note 9. 
types of market failure, regulators need to gather information about the activities of, and costs and benefits for, individuals and firms. They must first be able to determine when market conditions fail to meet the ideal of a well-functioning market. Then they must identify possible solutions and assess the consequences of different potential responses they might take. ${ }^{17}$

To identify whether firms are acting as monopolists, regulators need information about firms’ marginal costs of production. For utility regulation, they often need to know whether firms are making the kind of cost-effective choices about technology or management that they would make if the market were fully competitive. ${ }^{18}$ For social regulation that addresses externalities or seeks to ensure adequate product disclosure or safety, regulators need to know about the risks created by different types of products and production processes. Thus, they need to know about the nature and magnitude of any harmful activity or products, as well as the probability of such harm. Regulators also

17 We recognize, of course, that the regulators' information needs will not be the same for all alternative solutions. For example, regulators do not need the same information to restrict the quantity of an externality (such as pollution) as they do to require the adoption of specific control technologies or impose a tax on the same externality. See, e.g., Martin L. Weitzman, Prices vs. Quantities, 41 REV. ECON. STUD. 477 (1974); Evan Kwerel, To Tell the Truth: Imperfect Information and Optimal Pollution Control, 44 Rev. ECON. STUd. 595 (1977); Amyaz A. Moledina et al., Dynamic Environmental Policy with Strategic Firms: Prices versus Quantities, 45 J. EnVTL. ECON. \& MGT. 356 (2003). Although the choice of regulatory instrument will therefore affect the type and amount of information a regulator will need in any given context, the regulator will still always need some information about regulatory problems and their alternative solutions.

18 See Joskow and Schmalensee, supra note 12, at 16-17. 
need to understand the causes of regulatory problems. When the National Highway Traffic Safety Administration learns of a cluster of automobile accidents, it needs to find out whether the accidents occurred due to driver errors, road conditions, or mechanical problems. When the agency responded to blowouts in Firestone tires, for instance, NHTSA regulators needed to understand the extent to which tire separation was caused by factors such as heat or underinflation of tires, the tires' poor design or production, or the design or operation of the vehicles on which the tires were installed. ${ }^{19}$

Regulations usually specify actions that individuals or firms either must or must not take, so regulators must know what the possible behaviors they might require or prohibit. Particularly for problems of externalities or product hazards, regulators need to be able to specify technological or managerial options to change present operations and reduce risk. For example, environmental regulators need to know how oil refining, computer manufacturing, and other industrial operations can generate less pollution. Auto safety regulators need to understand what steps can be taken to prevent blowouts. Even when regulations set performance standards, regulators must often know about solutions in order to choose a feasible standard. ${ }^{20}$

${ }^{19}$ NHTSA, Engineering Analysis Report and Initial Decision Regarding EA00-023: Firestone Wilderness AT Tires, Oct. 4, 2001, available at http://www.nhtsa.dot.gov/hot/Firestone/firestonesummary.html (presenting competing analyses of the root causes of tire separation in Firestone tires); NHTSA, Proposed Rule on Tire Standards, 67 Fed. Reg. 10,050, 10,054-56 (Mar. 5, 2002) (analyzing factors leading to tire failure). After further study, NHTSA eventually did issue new standards for vehicle tires. NHTSA, Final Rule on Tire Standards, 68 Fed. Reg. 38,116 (June 26, 2003).

${ }^{20}$ This is especially the case for performance standards that are explicitly based on what is achievable by existing technologies. 
Finally, regulators need information about the probable (and actual, if known) consequences of different courses of action. ${ }^{21}$ These consequences include the extent to which a proposed regulation will deliver social benefits, such as enhanced safety or public health. They also include other effects, such as compliance costs, impacts on technological innovation, and the creation of additional harms or side effects. ${ }^{22}$ For example, if regulators at NHTSA seek to reduce fatalities from automobile accidents and are considering a requirement that manufacturers install air bags, they need to know more than just how well different types of air bags will reduce overall levels of injuries or fatalities. Price increases associated with an air bag mandate could reduce sales of new

${ }^{21}$ See, e.g., Richard Stewart, Reconstitutive Law, MARY. L. REV. (1986) (“Formulating centralized directives to control complex industrial and governmental subsystems involves exorbitant information and decision making costs. Enormous amounts of data must be centrally accumulated and analyzed in order to determine desired results and formulate the specific commands needed to achieve them.”). The practice of benefit-cost analysis in regulatory policy making presumes that information about consequences is relevant, even if not necessarily dispositive, in making regulatory policy. See, e.g., Kenneth J. Arrow, et al., Is There a Role for Benefit-Cost Analysis in Environmental, Health, and Safety Regulation?, 272 SCIENCE 221

(April 12, 1996) (defending benefit-cost analysis as "an economic tool for comparing the desirable and undesirable impacts of proposed policies”).

${ }^{22}$ Regulators also need information about expected compliance with different regulations, since full compliance is rarely achieved. Cf. Elizabeth Garrett, Harnessing Politics: The Dynamics of Offset Requirements in the Tax Legislative Process, 65 U. CHI. L. REV. 501 (1998) (noting the tendency of budget officials to "meet with affected parties to obtain information so that their projections will more accurately predict taxpayer behavior”). For a regulator, information about noncompliance with existing rules may even constitute a reason to issue new rules. 
and safer cars, or the air bags themselves might create new risks of harm, such as by deploying at high speeds into the faces of children or smaller-than-average adults. ${ }^{23}$

Regulators depend on information for nearly everything they do. ${ }^{24}$ The pages of the Federal Register are filled with information about regulatory problems, alternative solutions, and their consequences. Agency dockets and the offices of agencies' staff members contain still more information collected in connection with rulemaking. As Justice Breyer has observed, regulators' demand for information is “central and endemic” to the making of regulatory policy. ${ }^{25}$

\section{B. Industry's Informational Advantage}

When governmental intervention is needed to protect the public from harms arising largely independent of economic activity - such as perhaps the transmission of disease or natural climate variability - the relevant information may be acquired by government or independent researchers as easily as by regulatory agencies. Agencies may develop their own in-house expertise, and may also draw upon the expertise of academic researchers,

\footnotetext{
${ }^{23}$ See, e.g., Sam Kazman, NHTSA Air Bag Mandate Misfires, REG’N. 17 (Winter 1997)

${ }^{24}$ This holds true even if regulators are concerned mainly about protecting their own turf or maintaining their budgets. After all, even parochial regulators need information about their policies in order to predict and respond to reactions by interest groups and governmental overseers.

25 StePhen BREyer, Regulation AND ITS REFORM 112 (1982).
} 
independent consultants, or even the staff of advocacy groups. ${ }^{26}$ Such expertise tends to be general, say on the effects of air pollutants on health.

This kind of general expertise, however, is not sufficient when agencies must make decisions about particular industry practices. Internal agency experts, and even their outside consultants, will be at a disadvantage. Firms simply have much better access to the up-to-date and fine-grained information needed. ${ }^{27}$

Where government contemplates regulation to protect public health or safety, those engaging in the potentially harmful activity are likely to hold the relevant information or be able to obtain it more readily than the government. Manufacturing firms, for instance, almost always know much more than government about the risks associated with their products, technologies, and processes. ${ }^{28}$ They learn through their own testing, from reports of complaints by customers or workers, or just based on their superior understanding of the properties of their products and processes. For example, computer manufacturer IBM developed highly detailed in-house databases to track the chemicals used in IBM's production processes, the exposure of employees to these chemicals, and

\footnotetext{
${ }^{26}$ BREYER, supra note 1, at 109.

${ }^{27}$ David E.M. Sappington \& Joseph E. Stiglitz, Information and Regulation, in ELIZABETH E. BAILEY, ED., Public Regulation: New Perspectives on Institutions and Policies 3, 6 (1987) (noting that even if regulators do acquire information about firms’ production technologies, demand structures, and factor costs they do so "only with a lag, and indeed, in a rapidly changing environment, the information that they acquire may be of only limited relevance to the current situation”).

${ }^{28}$ Douglas C. Michael, Cooperative Implementation of Federal Regulations, 13 YALE J. ON REG. 535 (1996) (noting that firms are “more knowledgeable about the risks generated by their company’s operations").
} 
employees' medical histories. ${ }^{29}$ Through such internal tracking systems, firms can identify risks from their products and manufacturing processes long before government is able to learn of them. ${ }^{30}$ It is generally accepted that tobacco companies knew about the health risks from cigarettes decades before this information was known in governmental and public health circles. ${ }^{31}$ Chemical firms reportedly knew about health threats from vinyl chloride emissions long before government knew or could have known about them. ${ }^{32}$

Firms' informational advantage over government is usually even more pronounced for information about alternative solutions, such as how to reduce the emissions of vinyl

29 Gerald Hillman, ECHOES: IBM's Environmental, Chemical and Occupational Evaluation System, 24 J. OcCupational Med. 827 (1982); Spencer E. Ante, Was IBM Hazardous to Workers’ Health?, BusinESS WEEK, October 20, 2003, p. 46, 48.

30 Other major companies have implemented systems to track their impacts on occupational health and environmental quality. See R.E. Joyner \& Phil H. Pack, The Shell Oil Company’s Computerized Health Surveillance System, 24 J. OcCuPATIONAL MED. 812 (1982); Maureen T. O’Berg et al., Cancer Incidence and Mortality in the DuPont Company: An Update, 29 J. OcCuPATIOnAL Med. 245 (1987); Cary Coglianese \& Jennifer Nash, Bolstering Private-Sector Environmental Management, 17 IssuES SCI. \& TECH. 69 (Spring 2001).

${ }^{31}$ David Kessler, A Question Of InTENT: A Great AmERICAN BAtTLE WITH A DeAdLy Industry 182 (2001); MARTHA DERTHICK, Up IN SMOKE: FrOM LEGISLATION TO LITIGATION IN TOBACCO POLITICS (2001).

${ }^{32}$ Chemical Reaction, THE ECON. (March 31, 2001), available at http://www.economist.com/displayStory.cfm?Story_ID=550695. 
chloride. ${ }^{33}$ While firms may not have the incentive to acquire information about alternative solutions -- ignorance is a virtue if knowledge will lead to pressures to undertake costly changes to existing practices -- these private actors will have much more experience about how their activities might be modified to reduce or solve a problem. For example, automobile manufacturers will know better than government the options available for building safer cars or boosting mileage.

Most significantly, firms are better equipped to predict and identify the consequences of different regulatory options. Obviously, firms can better project their costs of producing goods or services under different regulatory standards. They can also better identify other consequences. For example, they will know how long it will take to incorporate new designs into their products and their manufacturing schedules, relevant information in deciding the length of any phase-in period for new regulations. Firms also generally have superior information about potential tradeoffs created by alternative rules. For example, regulators will want to consider whether changes in the fuel economy standards for cars will affect crash safety, something manufacturers can more easily assess. $^{34}$

\footnotetext{
${ }^{33}$ Cary Coglianese \& David Lazer, Management-Based Regulation: Prescribing Private Management to Achieve Public Goals, 37 L. \& Socy. Rev. 691, 695 (2003) (noting that firms “possess the most information about risks and potential control methods”).

${ }^{34}$ For a discussion of the potential tradeoff between fuel economy and automobile safety, see NATIONAL RESEARCH COUNCIL, EFFECTIVENESS AND IMPACt OF CORPORATE Average FuEL ECONOMY (CAFE) STANDARDS 113 (2002).
} 
It is often impossible for government agencies to conduct independent research to reproduce the information held by private actors. Even where possible, it is almost always more expensive, since firms have significant advantages in cumulative experience, technical skills, access to data, and research capacity, not to mention the fact that they own the production process. If firms already have the needed information, efforts by government to replicate it would be duplicative and wasteful. ${ }^{35}$

${ }^{35}$ We recognize, of course, that not all information provided by firms will be accurate, reliable, or helpful, and that relying exclusively and unthinkingly on the information provided by a single firm or industry can contribute to biased regulatory decision making. See PAUL J. QUIRK, INDUSTRY INFLUENCE IN FEDERAL Regulatory Agencies 17 (1981); Steven Croley, White House Review of Agency Rulemaking: An Empirical Investigation, 70 U. CHI. L. REV. 821 (2003) (suggesting that because “agencies rely so heavily on information about the consequences of regulatory alternatives from the very interests most affected by regulation, who therefore know the most about those consequences, agencies over time become unwittingly biased in favor of those they regulate”). Our claim is not that all or even most information supplied by industry will be the most valuable information to regulators, but rather that the best and most valuable information in many instances of regulatory policy making will be available only from industry. We are interested in those cases where industry holds reliable and accurate information that will help a regulator make a decision. In those cases where reliable and accurate information held by industry also supports the interests of that industry, we can expect that industry will readily release it. The problem we are addressing in this article is how to get valuable information from business when releasing that information does not advance industry’s interests. 


\section{The Strategy to Overcome Industry Silence}

Making effective regulatory policy depends on information that is often held by private actors, but government cannot count on self-interested holders of information to reveal it fully and without bias. ${ }^{36}$ Neither can it count on its power to compel the disclosure of information. Regulatory agencies can only mandate the disclosure of information when they are so authorized by Congress, ${ }^{37}$ and for many issues they lack such subpoena authority. ${ }^{38}$ Even when agencies do have authority, firms may resist or evade government demands. And when firms do release the precise information requested, they rarely generate anything more -- a distinct disadvantage when regulators are less certain about what they need to know. Far better, for regulators, is to find a cooperative source that will engage in give-and-take with the regulator, answering follow-up questions, providing background details that help the regulator fit the requested information into a larger pattern and to search for additional information when needed.

How can regulators secure information from those they regulate? In this Part, we begin by looking at this question from the standpoint of an industry. Since regulations affect entire industrial sectors, the release of relevant and accurate information from any

36 Stephen Breyer, Judicial Review of Questions of Law and Policy, 38 ADMIN. L. REV. 363, 388 (1986) (observing that industry has incentives to keep regulatory agencies’ from receiving information they need when setting regulatory policy).

37 See generally infra Part III.B.

${ }^{38}$ For example, the FDA lacked general subpoena power that it could use to gather information in its rulemaking involving the tobacco industry. DAVID KESSLER, supra note 31. 
actor within a given sector will help the regulator, but likely harm others in the sector -as when one tobacco company or asbestos manufacturer releases information to the government about the hazards of its products. The challenge for an industry, therefore, is to maintain a collective silence.

The information game between regulators and industry has a complex set of payoffs from information disclosure, and this complexity provides opportunities for government regulators to elicit the information they need to make effective regulatory policy. As we explain in this Part, the basic strategy is for the regulator to discover, exploit, and, if necessary, create asymmetric interests in the release of relevant information. The regulator must also address the risk of retribution that any disclosing party will likely face from others within industry.

\section{A. Industry Incentives and the Problem of Collective Silence}

The provision of information to support effective public decision-making benefits society on net. ${ }^{39}$ Yet potential targets of regulation will often lose, and therefore will

${ }^{39}$ Karl Claxton, Bayesian Approaches to the Value of Information: Implications for the Regulation of New Pharmaceuticals, 8 HEALth ECON. 269, 271 (1999) (“Information is non rival and a public good.”); Richard H. Pildes \& Cass R. Sunstein, Reinventing the Regulatory State, 62 U. CHI. L. REV. 1, 103 (“[I]nformation is sometimes a public good. Once it is available at all, or to anyone, it may well be available to everyone or to many people.”); William Mock, On The Centrality of Information Law: A Rational Choice Discussion of Information Law and Transparency, 17 J. MARSHALL J. COMPUTER \& INFO. L. 1069, 1085 (1999) (“The cost structure of information, including the ease of reproducing it and the fact that it is not lost to a transferor, makes most forms of information public goods.”). 
yield or withhold information strategically. Targets' decisions to produce information, and to reveal, bias, or conceal what they hold, will reflect their calculated attempts to influence the knowledge and perceptions of regulators so as to promote public decisions that either reduce their anticipated costs or increase their private benefits. ${ }^{40}$

An industry group as a whole will usually have an interest in maintaining silence, in retaining or not even generating information that would be adverse to the interests of private firms. ${ }^{41}$ Silence is preferred when regulators might use the information to make a decision adverse to the industry. The more regulators learn about individual firms'

40 See Roger G. Noll \& Bruce M. Owen, The Political Economy of Deregulation: Interest Groups IN THE RegUlatory Process (1983) (“[I]nterest groups have an incentive to withhold information that is inconsistent with their position and to present incomplete or biased information that supports their views.”); Edward A. Parson, The Technology Assessment Approach to Climate Change, 18 ISSUES IN SCI. \& TECH. 65 (2002) (“No company or industry has an interest in helping regulators to impose burdens on them.”).

${ }^{41}$ Our analysis also applies to the selective or biased release of information in a way favorable to industry's interests. However, for the sake of our analysis, we generally treat the informational decision facing industry to be a binary one: either disclose truthfully and fully, or not at all. We recognize that such a simplification abstracts away much of the subtleties in information transmission, leaving to the side selective transmission, signposting, framing, and spinning, and all sorts of important questions about interpretation. Richard Zeckhauser \& David V.P. Marks, Signposting: the Selective Revelation of Product Information, in Richard J. ZeCKHAUSER, RALPH L. KeENEy, \& JAMES K. SEBeniUs, EDS. WiSe Choices: DECISIONS, GAMES, AND NEGOTIATIONS (1996). We make this simplifying assumption here because our main purpose here is to bring clarity to the structure of incentives facing industry and the strategies available to government to identify and respond to those incentives. 
technological capabilities, the more able they will be, all things being equal, to design and justify more stringent requirements later.

Once someone releases information to the regulator, it usually cannot be retracted, ${ }^{42}$ and it usually leads to consequences that extend beyond the discloser. Thus all the firms within a relevant sector will have a collective interest in everyone’s maintaining silence. When no firm's benefits from revealing information outweigh its benefits from silence, there is no conflict between individual and collective interests; silence will prevail. But when firms' individual interests to reveal conflict with the industry's collective interest in silence, maintaining silence effectively becomes a problem of collective action. ${ }^{43}$ The collective action problem arises when there exists some good that all members of a group can share, but when each group member has an incentive to "free ride," i.e., let the others work to produce the collective good. For example, all citizens can enjoy the benefits of a cleaner environment, but each individual's share of these benefits is usually far smaller than the cost to any single individual to lobby successfully for new environmental

\footnotetext{
${ }^{42}$ Otto Keck, The Information Dilemma: Private Information as a Cause of Transaction Failure in Markets, Regulation, Hierarchy, and Politics, 31 J. CONFLICT ReSOL. 139, 152 (1987) (noting that "exchange of information is irreversible"). Disclosure by one actor may, of course, be disputed or contradicted by others. In some cases, the release of information by one actor may be insufficient to meet the regulator's needs, and still more information is needed from others. We discuss the implications of the order of disclosure infra at Part II.C.

${ }^{43}$ The quintessential collective action problem is getting individuals to make voluntary contributions to a common purpose, such as supporting a museum or a professional organization. For a discussion of the problem of collective action, see MANCur Olson, The Logic of Collective Action: Public Goods AND THE THEORY OF Groups (1965); RuSSELl HARDin, Collective ACtion (1982).
} 
regulations. Since individuals will be able to enjoy a cleaner environment regardless of whether they participated in any collective lobbying effort, each individual will have an incentive to free ride on the activities of others. The collective action that is optimal action for the group does not arise spontaneously.

A comparable tension between collective and individual interest exists with information. Each firm in the sector benefits from silence, but only if all firms do not disclose information to the regulator. Thus, industry faces a problem of "collective inaction" - to maintain silence. ${ }^{44}$

The immediate costs of concealing information are usually trivial, since silence typically requires taking no action at all; instead, the collective inaction challenge becomes severe when the consequences of regulatory decisions based on information released differ across firms. ${ }^{45}$ Some firms might not be harmed. Some firms may even benefit from disclosure (at least relative to their competitors). For example, if competitors differ in the costs of controlling a certain type of risk, it may be beneficial for a low-cost firm to disclose information about the risk to the regulator.

44 Parson, Zeckhauser, \& Coglianese, supra note 7.

${ }^{45}$ More precisely, these differences are ones of expected consequences. The expected value of silence and disclosure for any individual firm will reflect its predictions about the consequences of the action a regulator will likely take if certain information were to be disclosed. These predictions will be based on judgments about the behavior of the regulator, the degree of confidence the regulator will have in the information, and the responses of other group members to the disclosure of that information. 


\section{B. The Information Game}

The real world game among industry participants can best be understood with the aid of a game theory matrix. We illustrate for just two firms, but the lessons readily extend to cases with many. Each of the firms prefers the outcome where both Maintain Silence. If the game is fully symmetric, and the regulator intervenes no further, this outcome can be expected.

\begin{tabular}{|c|c|c|}
\hline & Fir & A \\
\hline & Maintain Silence & $\begin{array}{c}\text { Reveal Industry } \\
\text { Information }\end{array}$ \\
\hline $\begin{array}{l}\text { Maintain } \\
\text { Silence }\end{array}$ & 10,10 & 0,8 \\
\hline $\begin{array}{c}\text { Reveal } \\
\text { Industry } \\
\text { Information }\end{array}$ & 8,0 & 6,6 \\
\hline
\end{tabular}

In this situation, Firm A would reason as follows: "If Firm B is going to Reveal, I should as well. But if B Maintains Silence, I also want to Maintain Silence. However, B is insightful, and will see that the both Maintain Silence equilibrium is preferable for both of us than both Reveal. Thus, I will Maintain Silence.” Firm A will reason equivalently, and silence will be maintained.

We have presented the information game using illustrative payoff structures but the expected payoffs from silence and disclosure of particular pieces of information will often vary from firm to firm. Even if firms always made the same predictions about a 
regulator's actions (and they do not), those actions will affect different firms differently. Regulation can sometimes benefit certain firms, for example by raising barriers to entry by competitors. ${ }^{46}$ Firms that specialize in developing risk-reduction technologies will have interests that differ from firms that might be required to buy these technologies. Even among comparable firms in the same sector, there will be differences in the capacity and cost of each firm to respond to new regulations. If overall demand for a product is fairly inelastic, an increase in one firm's costs by, say, \$10 per unit may be worthwhile for that firm if it simultaneously increases competitors’ costs by $\$ 20$ per unit. Firms that are already leaders in their sectors in health, safety, or environmental protection will likely not be so affected by new regulations as so-called laggard firms. ${ }^{47}$ Firms that discover more benign industrial practices may believe they could reap a competitive advantage by revealing what they have learned to the regulator and encouraging the promulgation of new rules that will differentially burden their competitors.

In this situation, the game theory matrix will no longer be symmetric. Let us say that firm $\mathrm{A}$ is the one that gains by revealing information, particularly if B does not. The matrix might be as follows:

\footnotetext{
${ }^{46}$ See, e.g., George J. Stigler, The Theory of Economic Regulation, 2 BeLL J. ECON. \& MGT. SCI. 3, 3-6 (1971).

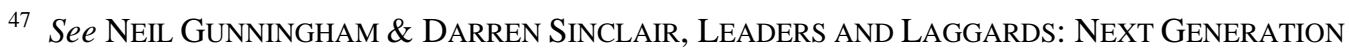
ENVIRONMENTAL REGULATION (2002).
} 
Firm A

\begin{tabular}{|c|c|c|c|}
\hline & Maintain Silence & Reveal Now & $\begin{array}{c}\text { Reveal if Firm B } \\
\text { Reveals }\end{array}$ \\
\hline $\begin{array}{l}\text { Maintain } \\
\text { Silence }\end{array}$ & 10,10 & 0,14 & Not applicable \\
\hline Firm B Reveal Now & 8,0 & 6,6 & 7,4 \\
\hline $\begin{array}{c}\text { Reveal if } \\
\text { Firm A } \\
\text { Reveals }\end{array}$ & Not applicable & 4,12 & Not applicable \\
\hline
\end{tabular}

In this game, Firm A will Reveal Now, since this is its preferred strategy no matter what B does. Firm B, anticipating this, will also Reveal Now, so as to receive 6 rather than 4 or 0 . Note the danger if firms do not know their counterpart's type. It may be that both firms have the payoffs of Firm B, but if they are sufficiently worried that the other firm may have payoffs like A, or indeed that the other firm may think that it has payoffs like A (even though they are like B), then the other firm will Reveal Now. Thus, the worrying firm should also Reveal Now. Thus, if there is sufficient uncertainty about payoffs, the situation may have a stable equilibrium where both Maintain Silence, but one or both parties may Reveal Now.

Regulators can themselves take action to affect firms' interests in disclosure. This strategy is well known in criminal law, where prosecutors cut deals with low-level 
employees or bit players in conspiracies if they share information. Thus, regulators try to turn Figure 1 situations into a Prisoners' Dilemmas, where both firms have an incentive to Reveal, although both would be better off if they both Maintained Silence. The regulator will also work to create less extreme situations, like the one illustrated in Figure 2. Identifying and working on the firms that have the greatest incentive to break silence, or agreeing to reward the first firm that breaks silence are strategies that help in this creation. It may also just be helpful to wander among firms searching for information, with vague hints that cooperators will get some reward. Each firm will worry that some other firm has an incentive to bolt the Maintain Silence equilibrium. When its worry gets large, that gives a firm an incentive to bolt first.

In Part III, we discuss the various ways that regulators can reward or punish individual firms based on whether they disclose information. ${ }^{48}$ Asymmetrical interests may also arise out of different beliefs about the likelihood that silence will successfully stave off new regulation. If it appears that a regulator intends to issue a regulation even in the absence of certain information, some firms may prefer to be perceived as "good citizens" and to release information in an attempt to shape the details of the new regulation.

Finally, firms are made up of individual people whose interests may vary. The individual employees or managers who make up a firm are the people who actually collect, analyze, and store information that may be of value to a regulator. Their interests

\footnotetext{
48 See infra Part III.
} 
will not, of course, always be fully aligned with the firm's overall interests; ${ }^{49}$ personal payoffs may differ from the payoffs to their firm. Individuals may not care about the benefits that silence brings to the firm as an organization, and they may sometimes find that cooperating with a regulator brings them personal benefits, such as by making it easier in the future for them to interact with the regulator on other matters related to their jobs.

In sum, payoffs to firms or individuals can depart from the industry's collective payoff from preserving silence in three ways. First, payoffs may differ among firms. Not all firms will oppose the revelation of specific information to the same extent, and some might even gain a comparative advantage from the resulting regulation. Second, regulators may seek to manipulate firms' payoffs for disclosure. Third, employees' interests may diverge from those of their firms.

As a result, an industry as a whole faces a challenge in maintaining collective silence. An industry needs to be able to threaten retribution on those who squeal. Retribution can range from various social sanctions inflicted against the managers of a squealing firm (e.g., yelling at them on the phone or withdrawing invitations to social events), to kicking the firm out of the industry trade association, to leaking information uniquely damaging to the squealing firm. (Why would firms disclose information adverse to a competitor only as retribution, instead of disclosing it preemptively? The reason is simple. If a firm did not hold back, it would then be the squealing firm and would itself be subject to retribution.) The risk of retribution is clearest for employees who disclose information

\footnotetext{
49 John W. Pratt \& Richard J. Zeckhauser, EdS., Principals and Agents: The Structure of BUSINESS 4 (1985).
} 
adverse to their employers: they lose their current job, and can expect difficulty finding employment elsewhere in the industry. ${ }^{50}$ Thus, the threat of retribution helps reinforce silence within an industry. Of course, when firms or individuals can disclose information to a regulator without it being known to others that they are disclosing, they can reduce the risk of retribution. For this reason, as we will see, there exists a heretofore unappreciated value to secrecy in the regulatory process.

\section{Informational Strategy for Regulators}

Regulators face two distinct scenarios in the disclosure of information. In the first, the interests within an industry are asymmetric, and the industry faces a challenge in maintaining collective silence. That is, some firms (or individuals) would expect to benefit from exposing certain information to the regulator; others would expect to lose. The regulator will seek to exploit these asymmetries and try to secure information from those who would expect to gain. In the second scenario, all firms' natural incentives are to maintain collective silence. The regulator will need to create new incentives, by offering rewards or punishments (or both) for the release of relevant and accurate information. In this section, we explain the payoffs underlying these two scenarios and develop general strategic considerations government regulators face in overcoming expected industry silence.

1. Exploit Asymmetries of Interests. Asymmetries of interest arise across different firms when firms face (or perceive that they face) different levels of harm from the

${ }^{50}$ See Cass R. Sunstein, Why Societies NeEd Dissent 6 (2003). 
disclosure of certain information. For example, in the 1970s, aerosol product firms tried to maintain a unified opposition to a ban on chlorofluorocarbon (CFC) propellants. As consumer resistance to aerosol products emerged, however, the S.C. Johnson Wax Company broke ranks and announced that it would remove all CFC propellants from its products. S.C. Johnson could take this position because it had developed water-based propellants twenty years earlier and used CFCs in only a small fraction of its aerosol products. ${ }^{51}$ The subsequent ban on CFC propellants was much less adverse to Johnson's interests as it was to other companies' interests, and could actually offer it some competitive advantage, at least in the short term.

To exploit asymmetries, regulators try to find the firms that are equivalent to the Johnson Wax Company. Since firms differ in the extent to which their business depends on a technology or practice of concern to regulators, perhaps because they have a substitute, regulators can try to elicit information from the firms likely to be affected least by a new regulation, but that still possess information that can be generalized across the industry. Firms that have already invested in strategies with lesser social impacts may actually prefer to disclose information that will promote regulation, or at least may be less opposed to its release. For example, prior to issuing a recent notice of proposed rulemaking on dietary supplements, the Food and Drug Administration (FDA) engaged in various public outreach and information-gathering efforts. The larger manufacturers shared information because they hoped that FDA's rulemaking "would establish a level playing field for industry, which would help prevent irresponsible firms from making and

51 L. DotTo AND H. SCHIFF, ThE OzOnE WAR (1978). 
selling adulterated products. ${ }^{\text {} 52}$ Firms at the forefront of their fields may even cultivate relationships with regulators, so that they can pass along information about innovative practices that regulators might make obligatory.

There are many differences beyond those between so-called "leaders and laggards.",53 Older firms may have interests that differ from newer firms. Suppliers' interests can differ from those of manufacturers. Firms selling to regional or niche markets may differ from firms selling to a broad, national market. Differences in firms' cost structures, technologies, and comparative abilities will affect attitudes toward disclosing information to regulators.

Firms also differ in the degree to which they are regulated. Some firms are affected by an entire series of regulations issued by a government agency, while other firms are affected by only a few of the agency's rules. Firms that interact with a regulatory agency on an ongoing basis will have a stronger interest in open and accurate disclosure of otherwise adverse information on a particular issue than firms that rarely interact with the agency; the former have more need to maintain their credibility with the regulator.

Regulators can also exploit asymmetries inside firms, by seeking information from employees, the so-called whistleblowers. Sometimes regulators receive employee

52 FDA, Proposed Rule on Dietary Supplements, 68 Fed. Reg. 12,158 (Mar. 13, 2003).

${ }^{53}$ See, e.g., Marissa Golden, Interest Groups in the Rule-Making Process: Who Participates? Who Gets Heard?, 8 J. Pub. AdMin. Res. \& THEORY 245, 262 (1998) (observing based on a study of HUD regulations that "businesses did not present a united front”); David M. Hart, Business Is Not an Interest Group (And, By the Way, There’s No Such Thing as “Business”): On the Study of Companies in American 
information passively. For example, New York’s attorney general, Eliot Spitzer, received a tip from a whistleblower in 2003 that suggested illegal market-timing and after-hours trading within the mutual fund industry. This prompted further investigation by the Securities and Exchange Commission and led to new regulations of the industry. ${ }^{54}$ Regulators often do not wait for employee revealers to step forward. For example, in the Food and Drug Administration's tobacco rulemaking in the 1990s, Commissioner David Kessler admitted that he "badly needed industry informants who could help [him] piece together the bits of information ... and make sense of it all." ${ }^{55}$ He directed his staff to track down current and former employees who might possess information to help the FDA build its case against tobacco. One informant the agency located "confirmed that the technology existed to make tobacco that was free of nicotine," a fact that the tobacco industry had undoubtedly tried to suppress. ${ }^{56}$

When exploiting potential asymmetries across or within firms, regulators must protect their sources from retribution. To this end, they treat sources confidentially. For

National Politics, Kennedy School Faculty Research Working Paper No. RWP02-032 (2002) (arguing that on many policy issues there are no common positions for all businesses).

54 Adrian Michaels, SEC Widens Investigation into Mutual Funds, FinANCIAL TiMES, Sept. 5, 2003, at p. 33 (reporting on SEC probe of the mutual fund industry launched after Attorney General Spitzer’s office received tip about market timing); Meet a Major-League Whistle-Blower, 60 Minutes II (February 19, 2004), at http://www.cbsnews.com/stories/2004/02/17/60II/main600649.shtml (accessed Mar. 20, 2004) (describing Wall Street insider Noreen Harrington's decision to go to Attorney General Spitzer’s office with information about marking timing).

55 KESSLER, supra note 31, at 112.

56 Id. at 115 
example, after providing assurances of confidentiality, FDA investigators did little more than appeal to civic duty to convince most tobacco informants to reveal information adverse to the their current or former employers. ${ }^{57}$ Regulatory agencies commonly provide protections for confidential business information, which allows firms to provide information without competitors' knowing what they revealed. ${ }^{58}$ Of course, it is also important that the regulator avoid using the information in a way that would hint at its underlying source. Double sourcing - revealing only when other confirmatory information has been obtained through other means - offers such protection. ${ }^{59}$

\footnotetext{
${ }^{57}$ KeSSLER, supra note 31, at 81, 83, 235.
}

${ }^{58}$ The Freedom of Information Act exempts agencies from disclosing "trade secrets and commercial or financial information obtained from a person and privileged or confidential.” 5 U.S.C. §552(b)(4). In addition, the Trade Secrets Act provides additional protection for certain confidential business information. 18 U.S.C. §1905. While such protection can be valuable even when government mandates disclosure, such protection of confidentiality will be even more critical when government is seeking information voluntarily by exploiting asymmetries of interests, given the potential competitive or retributive consequences if the revealer is found out. The D.C. Circuit Court of Appeals has recognized the need to protect the confidentiality of business information precisely to encourage continued cooperation by industry in informing government decision makers. Critical Mass Energy Project v. Nuclear Regulatory Commission, 975 F.2d 871 (D.C. Cir. 1992). In an en banc decision, the court interpreted section 552(b)(4) of the Freedom of Information Act to exempt disclosure of virtually any business information voluntarily submitted to the government. Id.

${ }^{59}$ In some cases, regulators will be able to, or will need to, use information leaked to it as a basis for issuing orders for further information. For example, the tips state officials received about practices in mutual fund firms helped the SEC know what information to order funds to disclose, something which it 
Regulators may also offer to protect whistleblowers against reprisals from their employers. For example, the Nuclear Regulatory Commission has issued regulations that prohibit nuclear facilities from firing, reducing the salary, or otherwise discriminating against employees who report violations to the NRC. ${ }^{60}$ It has also issued rules that prohibit employers from including "no-talk” provisions in agreements settling employment discrimination disputes, finding that such restrictions can "have a chilling effect on communications about nuclear safety, security, or other matters, and would restrict, impede, or frustrate full and candid disclosure to the Nuclear Regulatory Commission about matters of regulatory significance.”,61

2. Create Incentives. When regulators cannot identify sources that might reveal, or suspect there are none, they are in the second scenario. The regulators must create new incentives to break industry’s silence, i.e., to get firms to disclose information. ${ }^{62}$

has now done for many financial institutions in the mutual fund business. We discuss the relationship between the different strategies further in Part II.A.3.

60 Nuclear Regulatory Commission, Whistleblower Protection for Employees of NRC-Licensed Activities, 58 Fed. Reg. 52406 (October 8, 1993).

${ }^{61}$ Nuclear Regulatory Commission, Preserving the Free Flow of Information to the Commission, 55 Fed. Reg. 10,397 (March 21, 1990).

62 There is a symmetry here with the conventional problem of collective action. One of the well-known solutions to this problem is the provision of selective benefits. Political interest groups organized to promote collective interests routinely offer gifts, discounts, magazines, or travel benefits to solicit new members. They also serve as nodes for valuable networking for business or social purposes. OLson, supra note 43; Robert Salisbury, An Exchange Theory of Interest Groups, 13 MiDWEST J. POL. SCI. 1 (1969); JAMES Q. WiLson, Political ORganization (1973). 
Regulators can issue information requests under a threat of some penalty. For example, when the SEC in 2003 ordered mutual funds to turn over information related to possible market timing and after-hours trading activity, its request detailed the civil penalties for noncompliance. ${ }^{63}$ Even a "voluntary" request for information may carry an implicit risk that failure to demonstrate good faith compliance might subject the firm to a closer and more extensive investigation by the regulator.

Regulators can also reward firms that come forward with needed information. In crafting a new regulation, it is sometimes possible to design a rule, or mode of enforcement, to vary the burden imposed on particular industries or firms, effectively (though not explicitly) giving favorable treatment to firms that provide information. As we discuss further in Part III, some regulatory agencies have even established recognition programs that try to reward firms that act responsibly and are willing to engage in information sharing with the agency.

Beyond creating incentives for individual firms, regulators can use their regulatory authority to shape overall industry incentives. If the government can credibly signal that it will issue a new regulation whether or not it receives certain information from the industry, firms may choose to disclose otherwise adverse facts in the hope of forestalling an even more stringent or costly regulation. Firms may also find some value from acting like a "good citizen" if they think the regulator already has enough information to create a regulation that will withstand judicial scrutiny. Regulators, like shrewd prosecutors trying to break down conspirators, may feign more knowledge than they have.

${ }^{63}$ See supra note 54. Section 21c of the Securities and Exchange Act of 1934 provides for judicial enforcement of SEC information demands and criminal penalties for failure to comply. 
Finally, industry’s response to new regulations can give regulators information needed to tighten or refine these regulations still further. For example, the Montreal Protocol required a 50 percent reduction in industry's use of CFCs and established a technology assessment panel to identify ways to meet this target. ${ }^{64}$ Since the entire industry now faced incentives for finding ways of reducing their use of CFCs, participation on the assessment panel provided an opportunity for firms to pool their expertise to achieve innovations. ${ }^{65}$ The results included new information that proved helpful to industry and yielded positive externalities: the collective search led to the use of less harmful chemicals and new technological processes that reduced the use of ozonedepleting chemicals by more than 95 percent. $^{66}$

\section{Additional Strategic Considerations.}

Our analysis of regulators' basic strategies raises three implications. First, effective regulatory decision making depends on more than just scientific, economic, and engineering information. It also requires political information, that is, information about the interests and proclivities of affected firms and individuals. Regulators must understand the various interests at stake if they are going to try to exploit asymmetric interests, even when using rewards or punishments. How do regulators find out about

\footnotetext{
${ }^{64}$ Protocol on Substances that Deplete the Ozone Layer, Sept. 16, 1987, S. Treaty Doc. No. 100-10, 1522 U.N.T.S. 293, reprinted in 26 I.L.M. 1541, 1552-54 (1987).

${ }^{65}$ Edward A. Parson, Protecting the Ozone Layer: Science And Strategy (2003). ${ }^{66} I d$.
} 
firms' interests in disclosure? Often information about interests comes from ongoing interactions between regulators and the industries they regulate. Regulators may also issue advance notices of proposed rulemaking to flush out interests. In a preplay to the main round of the game, the nature and intensity of firms' responses to regulators' initial forays reveals information about their underlying interests. ${ }^{67}$

Second, regulators will usually both exploit asymmetries and provide incentives that create them. They may use both strategies in tandem, such as by issuing an information request backed up by penalties and also separately (but discretely) targeting individual firms with differential interests to obtain other information. Or they may combine the two strategies into one effort, such as by rewarding those firms already most inclined to disclose. They may also stage the two strategies when searching for the same information. Regulators who exploit asymmetries can later try to create incentives.

Regulatory problems often have several plausible causes, and they almost always have several potential solutions. The value of any particular piece of information for the regulator depends on how effectively it fills a gap in the regulator's knowledge base and how important that gap is to the regulator's overall decision making. For firms, the costs and benefits of providing any given piece of information also vary, depending upon the likely consequences of disclosure. The regulator will thus wish to downplay the significance of any information it seeks from a potential source, and to pursue different pieces of information from different actors, so that it will be harder for any one of them to

${ }^{67}$ See Johnston, supra note 12. 
see how the pieces fit together. ${ }^{68}$ In this way, regulators are not unlike the police investigating a crime. They go around asking many people for small bits of information and then attempt to piece it all together.

Firms with a hazy picture of the regulator's overall puzzle will be less likely to assess accurately the value and impact of the release of any particular piece of information. ${ }^{69}$ Some firms will overestimate the value of their information to the regulator and will therefore resist disclosure; others will underestimate the regulator's use of what they say, and will release more information than they otherwise would. For example, in building its case for tobacco regulation, FDA investigators interviewed tobacco farmers about some of the experimental crops they grew in an effort to show how the industry had developed techniques to control the levels of nicotine in cigarettes. ${ }^{70}$ Undoubtedly, few farmers who talked to agency investigators fully appreciated how the FDA would use information about their crops to build a case against the tobacco industry. And surely no experienced government investigator would have conveyed to these farmers that the fate of the tobacco industry rested in the information they were being asked to provide.

\footnotetext{
${ }^{68}$ The regulator will face a tradeoff in deliberately soliciting information from different sources for the purpose of avoiding showing all its cards to any single player. The accuracy and usefulness of information may well diminish the more sources from which it comes, especially if different sources used different units of measurement and the regulator is unable to convert the data into a common metric. In such cases, the regulator will be better off pursuing information from a single source, even if doing so will reveal more fully to that source the value of the information the regulator needs.

${ }^{69}$ Thus, firms have an incentive to cooperate with the regulator when the regulator cooperates in return and shares information about the agency's plans. See infra note 151 and accompanying text.

${ }^{70}$ KesSLER, supra note 31.
} 
A third consideration emerging from our strategic analysis is that regulators need to consider in what order they will pursue different sources of information. ${ }^{71}$ Regulators will want to distinguish between sources of information according to how valuable their information is. It may be better for regulators first to pursue information from sources possessing lower information value, building up their base of knowledge so that they can later maximize what they learn from their most intelligent sources of information. Of course, since regulators often do not know what they are hunting for, they may not know which sources will be most valuable ones until well into an inquiry.

As a general guideline, regulators should try to exploit asymmetries before attempting to create incentives. A regulator's initial step in any regulatory proceeding should be to determine which firms (or individuals) are likely to have asymmetric interests with respect to different pieces of relevant information. ${ }^{72}$ It may take time to find a willing source of information, but if the agency can afford the delay this is generally preferable to mandating disclosure, which sets up an adversarial posture that can be difficult or impossible to unwind. ${ }^{73}$ But when regulators believe that there is a low probability of finding any cooperative source or if the problem is particularly urgent, it may be better to

\footnotetext{
${ }^{71}$ Correspondingly, industry's collective ability to inflict retribution on those who disclose information will also likely vary depending on the order of revelation. Whether by regulators or by industry, the strongest incentives - positive or negative - may be applied to those firms who disclose (or threaten to disclose) first. See Parson, Zeckhauser, \& Coglianese, supra note 7.

72 See infra notes 173-75 and accompanying text.

73 See supra notes 86-97 and accompanying text.
} 
use their subpoena power at the outset. ${ }^{74}$ Mandatory disclosure may also be more appropriate when regulators are looking for confirmation of something they already know.

\section{Regulators' Tactics for Eliciting Information}

In this Part, we consider the specific tactics that regulators use to exploit asymmetries of interest and to create new incentives for disclosure. Legal commentators generally distinguish between forms of voluntary disclosure of information and compulsory disclosure, ${ }^{75}$ and pay more attention to compulsory inspections and subpoenas, which

74 There may also be strategic reasons for regulators to issue subpoenas before exploring other options, regardless of the relative merits of mandated disclosure in terms of collecting valuable information. Issuing a subpoena conveys to Congress and the public an impression that the regulator is taking swift action to address a problem and it also tends to put the firms that are subject to a subpoena in a bad light, which may distract attention from criticisms of the regulator. Agencies do publicize their issuance of administrative subpoenas, behavior that confirms the strategic value to mandated disclosure entirely apart from its value for securing information. For recent accounts of regulators' high-profile probes into practices in the mutual fund industry, see Scott Bernard Nelson, US, State Broaden Inquiry of Funds: More Firms Get Notes Seeking Information, The Boston Globe, Sept. 6, 2003, at C1; Ellen Kelleher, US Extends Probe to Include Intermediaries, Financial Times, Oct. 13, 2003, at 27; Adrian Michaels, SEC Puts Pressure on Mutuals, Financial Times, Oct. 30, 2003, at 16.

75 Richard J. Pierce, I Administrative LaW Treatise 194 (4 ${ }^{\text {th }}$ ed, 2002) (“[A]lmost all the information the agencies receive from private parties comes in voluntarily. In both adjudication and rulemaking, whether formal or informal, private parties voluntarily submit the facts about themselves, and they usually answer questionnaires without compulsion.”); JERRY L. MASHAW, RICHARD A. MERRILL, AND PETER M. 
raise issues about privacy and protections against self-incrimination. ${ }^{76}$ Yet the tactics available to regulators are actually quite diverse: (a) disclosure as a precondition for regulatory decisions; (b) mandatory reporting and access; (c) rewards for disclosure; (d) nonmandatory information requests; (e) formal interaction; and (f) informal interaction.

\section{A. Conditioning Decisions on Disclosure}

Regulators sometimes condition key decisions on the disclosure of information by regulated firms. ${ }^{77}$ For example, companies must submit extensive information to the FDA to secure its approval to market new drugs. ${ }^{78}$ The Federal Aviation Administration (FAA) requires manufacturers of new aircraft to submit extensive test results before the

Shane, Administrative Law: The American Public LAW System $5^{\text {th }}$ ed (2003) (“Agencies obtain needed information in a variety of ways. Most of it is provided voluntarily....However, some information that government officials require to develop policy...is not willingly disclosed.”).

${ }^{76}$ See, e.g., Carlos B. Castillo, Discord Among Federal Courts of Appeals: The Constitutionality of Warrantless Searches of Employers' OSHA Records, 45 U. MiAMI L. REV. 201 (1990); Susan M.

McDonough, The Fourth Power? Administrative Searches vs. The Fourth Amendment, 20 N.E. J. ON CRIM. \& CIV. Con. 195 (1993); Geoffrey G. Hemphill, The Administrative Search Doctrine: Isn't This Exactly What the Framers Were Trying to Avoid?, 5 REGENT U. L. REV. 215, 217 (1995).

77 The Office of Management and Budget estimates that 39.7\% of all authorized information collection requests are "required to obtain or retain some kind of benefit.” OMB, Final Report of the Small Business Paperwork Relief Task Force 7 (June 27, 2003).

${ }^{78}$ Pharmaceutical firms must file new drug applications that include all the data and findings from any clinical trial performed on a drug they would like to market. 21 U.S.C. $§ 355$. If the agency finds that the data show that the drug meets the requirements for safety and efficacy, it will approve the drug for market. 
agency will certify the design as meeting applicable safety standards. ${ }^{79}$ While such transfers of information take place in case-by-case proceedings instead of general policy making, the information about the industry the agency gains may prove helpful in subsequent rulemakings by the agency or by other agencies.

Firms have incentives to submit selective, biased, or even false information to satisfy disclosure requirements. ${ }^{80}$ For example, in its application to market a drug called Oraflex, the pharmaceutical company Eli Lilly failed to disclose overseas deaths associated with the use of Oraflex. ${ }^{81}$ By the time the company pleaded guilty and was

\footnotetext{
${ }^{79}$ See Federal Aviation Act of 1958, Pub. L. No. 94-12, 72 Stat. 731 (codified as amended in sections of 14, 15, 16, 31, 40, 48, and 49 U.S.C.). 14 C.F.R. § 21.33(b) (manufacturer must make all inspections and tests); 14 C.F.R. § 21.35(b) (manufacturer must make all flight tests). See generally Mark A. Valetti, Comment, Preemption of State Law Tort Claims in the Context of Aircraft Manufacturers, 60 J. AIR L. AND CoM. 699, 705-710 (Dec. 1994/Jan. 1995) (describing the FAA certification process). In addition, the manufacturer must demonstrate that it has in place a quality control system to ensure that its production process will consistently produce aircraft that meet the approved design. See 14 C.F.R. § 21.139; 14 C.F.R. $\S 21.143$ (noting what data must be provided to demonstrate quality control); 14 C.F.R. § 21.135 (certification will be issued if application meets requirements of $\S 21.139$ and 21.143). These detailed plans describe the processes manufacturers use to meet safety requirements, providing information about each firms' production.

${ }^{80}$ These incentives will be affected by the penalties for submitting inaccurate or incomplete information and the probabilities of getting caught.

${ }^{81}$ See Teresa Moran Schwartz, The Role of Federal Safety Regulations in Products Liability Actions, 41 VAND. L. ReV. 1121, 1148 n.124 (1993). See also Morton Mintz, Indictment Accuses Drug-Testing Firm of Falsifying Results, THE WASHINGTON POST, Jun. 1, 1979, at A9 (describing allegations of falsification by another drug company).
} 
forced to withdraw the drug from the market, the drug reportedly had caused about 50 deaths in the United States. ${ }^{82}$

Regulators usually cannot independently verify the information firms provide, and often it is hard to detect subtle inaccuracies in the data or the firms' analysis.

Overcoming this problem requires large penalties for false disclosure or ones that apply to individual decision makers directly. ${ }^{83}$ Congress took this approach in the SarbanesOxley Act of 2002, which increased penalties for corporate fraud and required individual certification by CEOs of the accuracy of company filings. ${ }^{84}$

At times, regulators can use information from firms' applications submitted to other agencies. For example, to understand the tobacco industry's techniques, the FDA relied on information submitted to the Patent Office in support of tobacco companies’ patent applications. Tobacco companies touted their innovative methods of controlling nicotine levels when applying for patents related to cigarette manufacturing; this information later helped the FDA build its case that cigarettes were sophisticated drug delivery devices that warranted the FDA's regulatory control. ${ }^{85}$

\footnotetext{
${ }^{82}$ See Teresa Moran Schwartz, Punitive Damages and Regulated Products, 42 AM. U. L. REV. 1335, 1348 (1993).

${ }^{83}$ See Sidney Shapiro, Divorcing Profit Motivation From New Drug Research: A Consideration of Proposals to Provide the FDA with Reliable Test Data, 1978 DuKE L.J. 155, 170 (1978) (questioning the ability of FDA officials to detect subtle biases in the data they receive); Schwartz, supra note 82, at 115758.

${ }^{84}$ Pub. L. 107-204, 116 Stat. 745 (July 30, 2002).

${ }^{85}$ KeSSLER, supra note 31, at 122-24 (evidence from patent applications showed that industry had developed the means of manipulating nicotine levels in cigarettes). Of course, FDA's efforts to regulate
} 


\section{B. Mandatory Reporting and Access}

Regulators can mandate that firms release information or submit to government audits or inspections, with the threat of penalties if firms do not comply. ${ }^{86}$ Mandated information disclosure can take the form of subpoenas, reporting requirements, and government inspections of facilities.

It is well established that Congress and the courts have the authority to order the disclosure of information. ${ }^{87}$ Regulatory agencies can also compel businesses or individuals to answer questions or produce documents, as long as Congress has given them this authority by statute and they request information that is relevant to a legitimate

tobacco ultimately were not sustained in court, as the U.S. Supreme Court held that tobacco products were specifically excluded by statute from FDA’s jurisdiction. FDA v. Brown \& Williamson Tobacco Corp., 120 S.Ct. $1291(2000)$.

${ }^{86}$ The Office of Management and Budget estimates that 38.4\% of all authorized information collection requests "are mandatory where failure to provide the information required can result in civil, or criminal, sanctions.” OMB, supra note 77, at 7.

${ }^{87}$ Congress has the power to compel witnesses to testify or produce documents so that it can more competently exercise its legislative authority. McGrain v. Daugherty, 273 U.S. 135 (1927). See generally John M. Landis, Constitutional Limitations on the Congressional Power of Investigation, 40 HARV. L.REV. 153, 189 (1926). Courts can compel the disclosure of information in litigation, which on occasion will prove to be an additional source of information for regulators. Fed. R. Crim. P. 17; Fed. R. Civ. P. 37, 45. The litigation filed by smokers and state attorney generals yielded documents helpful to the FDA in its rulemaking on cigarettes. KESSLER, supra note 31. 
agency purpose and is not patently unreasonable. ${ }^{88}$ The courts allow agencies granted such authority to use it to obtain information for rulemaking as well as enforcement. ${ }^{89}$ Courts have generally deferred to regulators when it comes to enforcing information requests, even upholding broad requests for “all papers” or "all documents” related to issues of concern to the regulator. ${ }^{90}$ Indeed, the courts have held that mere "official curiosity” is a sufficient purpose for mandatory information requests, provided the information requested pertains to a matter within the agency’s authority. ${ }^{91}$

Regulators can also compel firms to file routine reports that effectively enable government to monitor relevant aspects of an industry. For example, under the Toxic Substances Control Act (TSCA), the Environmental Protection Agency (EPA) requires

\footnotetext{
${ }^{88}$ U.S. v. Morton Salt, 338 U.S. at 654; Endicott Johnson v. Perkins, 317 U.S. 501, 509 (1943) (agency orders will be sustained unless "plainly incompetent or irrelevant to any legal purpose" of the agency). For example, the Federal Trade Commission has the authority "to require by subpoena the attendance and testimony of witnesses and the production of all such documentary evidence relating to any matter under investigation.” 15 U.S.C. § 49. However, even when statutes contain authorizations to conduct physical inspections of facilities, the Supreme Court has held that in certain situations regulators may be required to obtain search warrants prior to making an inspection in the absence of a firm's consent. Marshall v.

Barlow’s, 436 U.S. 307 (1978).

${ }^{89}$ FTC Line of Business Report Litigation, 595 F.2d 685, 702.

${ }^{90} I d$. at 703 ("When the inquiry is conducted pursuant to a lawful purpose and the request is relevant to that objective, its reasonableness will be presumed absent a showing that compliance threatens to disrupt or unduly hinder the normal operations of a business.”). See also Morton Salt Co., 338 U.S. 632, Phillips Petroleum v. Lujan, 951 F.2d 257, 260, (10 ${ }^{\text {th }}$ Cir. 1991).

${ }^{91}$ Morton Salt Co., 338 U.S. at 652.
} 
companies to disclose scientific studies they have conducted on toxic substances ${ }^{92}$ and to report data on production levels of chemicals listed on the agency’s Chemical Substances Inventory. ${ }^{93}$ The EPA uses such data to help set priorities, assess new risks, and establish and implement agency regulations. ${ }^{94}$ Firms that fail to report the required information may face court-ordered fines of up to $\$ 25,000$ per day for each violation.

Mandatory reporting does have the advantage that it may overcome selection bias, as voluntary disclosure is more likely to elicit information from a unrepresentative sample of firms, namely those with favorable information to reveal. ${ }^{95}$ Unfortunately, such mandatory extractions suffer three shortcomings. First, requests for information can be politically unpopular, particularly if they require a lot of effort by the industry to respond to them. To limit government information requests, for example, Congress has adopted the Paperwork Reduction Act, which requires agencies to obtain approval from OMB for

\footnotetext{
${ }^{92}$ Toxic Substances Control Act, 15 U.S.C. § 2607(d); 40 C.F.R. § 716.

${ }^{93}$ See 15 U.S.C. § 2607; Partial Updating of TSCA Inventory Data Base; Production and Site Reports, 51 Fed. Reg. 21,438 (Jun. 12, 1986).

${ }^{94}$ Partial Updating of TSCA Inventory Data Base; Production and Site Reports, 50 Fed. Reg. 9944 (proposed Mar. 12, 1985) (stating that EPA uses the information it receives to "set priorities for further investigation, ... to estimate, along with other data, the potential for human and environmental exposure to specific substances, to support the implementation of various TSCA regulations, and to perform economic impact analyses for potential TSCA regulations”).

${ }^{95}$ For an analogous scenario in the regulation of disclosure of information to consumers, see Howard Beales, Richard Craswell, and Steven Salop, The Efficient Regulation of Consumer Regulation, 24 J. L. \& ECON. 491, 537 (1981) (noting that when disclosure is voluntary "information will usually be disclosed only by sellers of whom it speaks well”).
} 
any information requests that ask identical questions of more than ten individuals or companies. ${ }^{96}$ Second, to be effective, mandatory information requests require that the regulator already has enough information to know what issues to ask about. Firms are unlikely to respond to a subpoena by volunteering information beyond what is required. Third, it is generally hard for government to determine whether firms have provided complete responses. A failure to make any response will be clear, but it is extremely difficult to demonstrate omission or evasion if the firm responds with at least some information. A recent amnesty program administered by the EPA under TSCA shows the nondisclosure problem can be extensive. The EPA established a five-year amnesty period, waiving penalties for firms that came forward with studies on toxic substances they had previously failed to disclose. ${ }^{97}$ Companies disclosed 11,000 old studies that had previously gone undisclosed. ${ }^{98}$

\section{Rewards for Disclosure}

The EPA's amnesty program was actually an example of a reward for disclosure. Through this program, the EPA offered firms something of value - namely, amnesty - in

\footnotetext{
9644 U.S.C. § 3502(3).

${ }^{97}$ See Marianne Lavelle, EPA’s Amnesty Has Become a Mixed Blessing: Be Careful What You Ask For, NAT. L.J., Feb. 24, 1997, at A1.

${ }^{98}$ Id. Some companies claimed that they had failed to submit the older studies because of ambiguity about whether they were required to do so, not out of any obstructionist intent. A similar amnesty program for
} 
exchange for information. Regulators' rewards are often much more discreet. For example, regulators may become valued and trusted sources of information about agency activities for industry representatives who are valued and trusted sources of information for regulators.

Although difficult to document, it is plausible that regulators sometimes design rules that subtly reward firms that provide information. ${ }^{99}$ In negotiations over multi-state tobacco litigation, for example, the Liggett Group sought special treatment in part because the company had previously reached a deal releasing documents that revealed the tobacco industry's efforts to cover up smoking's hazards. ${ }^{100}$

production data for chemicals listed on EPA's inventory apparently netted new information from about 250 companies. Id.

${ }^{99}$ For example, government could adopt a technology-based standard that locks in a technology that the firm already uses would put competitors at a disadvantage, whereas a performance-based standard might not.

100 Tobacco's Crumbling Barricades, NEW YoRK TIMEs, March 22, 1997, p. 22. Liggett also claimed it could not afford its share of the settlement. Carrick Mollenkamp et AL., The People vs. Big Tobacco 224 (1998). In the end, however, Liggett was unable to secure an exemption from the terms of the settlement, in large part because the rest of the industry closed ranks. Id. at 224, 233. Although this is an example of information disclosure in litigation, for an argument that large-scale litigation over social issues such as tobacco has effectively become a form of regulation, see W. KIP VISCUSI, ED., REGULATION THROUGH LiTigATION (2002). 
Over an extended time, many opportunities will arise for regulators to offer implicit benefits to firms that release relevant and accurate information. ${ }^{101}$ In repeated interaction, especially when information is the currency of exchange, building a reputation matters since a regulator needs to be able to trust the information provided to it by an industry source. By providing information adverse to its interests, at least once in a while, a firm can bolster its credibility as an industry source, making it more likely that the government will grant the firm some implicit benefit -- if only by believing the firm even when other information it shares seems self-serving. This is especially relevant for information about industry costs or technological feasibility.

Regulators have also developed programs that deliver explicit inducements to firms if they deliver helpful information to the government. These programs, which are often justified as efforts to reward firms for achieving outcomes superior to what is normally required, also allow regulators to learn about best practices. For example, in the area of environmental and occupational safety regulation, agencies now offer explicit benefits to encourage firms to participate in various pilot projects or reveal information about their management practices. Firms that commit to taking on extra measures and are willing to provide the government with more information about their products or

${ }^{101}$ Given that many firms and trade associations are engaged in long term, repeated interaction with regulatory officials, they will find benefits over the long term from cooperative and open dealing with government. Robert AXELROD, Evolution of COOPERATIOn (1984); Coglianese, supra note 6. 
practices than is normally required receive special recognition, reduced enforcement scrutiny, and in sometimes outright exemptions from existing standards. ${ }^{102}$

For example, after receiving a series of health complaints from neighbors of large animal feedlot operations, the EPA began investigating whether it should take regulatory action to address the situation. To collect information, the EPA initiated negotiations with firms to induce them to implement monitoring systems on their facilities to provide EPA with data on the pollutants in the air at feedlots. ${ }^{103}$ In exchange for firms' willingness to install monitoring devices, the EPA reportedly offered to "give farm operators amnesty for any Clean Air Act violations” that the Agency uncovered through the monitoring program. ${ }^{104}$

Another type of inducement offers exemptions from existing regulations. ${ }^{105}$ EPA's Project XL, established in the mid-1990s, allows the EPA to grant waivers if firms show that they will use alternative methods of pollution reduction that will yield better environmental results than the methods specified under current regulations. ${ }^{106}$ Intel, for

102 See generally David W. Case, The EPA's Environmental Stewardship Initiative: Attempting to Revitalize a Floundering Regulatory Reform Agenda, 50 EMORY L.J. 1, 4 (2001); Cary Coglianese \& Jennifer Nash, Policy Options for Improving Environmental Management in the Private Sector, 44 ENVIRONMENT 10 (November 2002) (describing government programs to recognize best practices). 103 Jennifer Lee, Neighbors of Vast Hog Farms Say Foul Air Endangers Their Health, New York Times, May 11, 2003.

${ }^{104} \mathrm{Id}$.

${ }^{105}$ See Bradley C. Karkkainen, Adaptive Ecosystem Management and Regulatory Penalty Defaults: Toward a Bounded Pragmatism, 97 MinN. L. ReV. 943, 965-970 (2003).

106 See EPA, Regulatory Reinvention (XL) Pilot Projects, 60 Fed. Reg. 27,282 (May 23, 1995). 
example, devised an alternative strategy for reducing air pollution at one of its Arizona semiconductor facilities in exchange for the EPA’s waiving certain regulatory permitting requirements. ${ }^{107}$ Project XL was designed in part to provide the EPA with information about alternative environmental strategies that the agency could use to develop new environmental regulations or revise old ones. ${ }^{108}$ Firms applying for waivers must provide the EPA with a substantial amount of information about the alternative strategies they propose and submit to an ongoing monitoring regimen. ${ }^{109}$

Both the EPA and the Occupational Safety and Health Administration (OSHA) also offer public recognition as an inducement to gather information from firms that exhibit

107 See John H. Cushman, Jr., E.P.A. and Arizona Factory Agree on Innovative Regulatory Plan, N. Y. TIMES, Nov. 20, 1996, at A18. See also Lawrence E. Susskind \& Joshua Secunda, The Risks and the Advantages of Agency Discretion: Evidence from EPA's Project XL, 17 UCLA J. ENVTL. L. \& POL'Y 67 (1998-99); Daniel Fiorino, Toward a New System of Environmental Regulation: The Case for an Industry Sector Approach, 26 EnVTL. L. 457 (1996); Allen Blackman \& Jan Mazurek, The Cost of Developing SiteSpecific Environmental Regulations: Evidence from EPA's Project XL, Resources for the Future Discussion Paper No. 99-35 (Apr. 1999).

108 Thomas E. Caballero, Project XL: Making It Legal, Making It Work, 17 STAN. ENVTL. L.J. 399 (1998) ("The Clinton administration conceived Project XL as a means of experimenting with new methods of controlling and reducing pollution through pilot projects. The knowledge gained from the projects was supposed to facilitate the modification of environmental regulations and controls.”). For a further discussion of the purposes of Project XL, see Dennis D. Hirsch, Project XL and the Special Case: The EPA's Untold Success Story, 26 Colum. J. EnVTL. L. 219, 220-227 (2001); Alfred A. MARCUS, ET AL., REINVENTING ENVIRONMENTAL REgULATION: LESSONS FROM PROJECT XL (2002).

${ }^{109}$ See EPA, 60 Fed. Reg. at 27,287 (noting that one of the requirements is monitoring, reporting and evaluation of the program). 
best practices in environmental and workplace safety management. OSHA’s Voluntary Protection Programs (VPP), created in 1982, has more than 1,000 member facilities nationwide. ${ }^{110}$ Under the VPP program, OSHA exempts from regular inspections employers who demonstrate a strong record in health and safety and have approved health and safety programs in place. ${ }^{111}$ As part of the application process, OSHA conducts a rigorous "pre-approval review" that provides the agency with information about firms' health and safety measures. ${ }^{112}$ OSHA also goes on-site to inspect the employer's past safety records, review its policies and procedures for ensuring health and safety, and interview managers and employees about the policies and controls. ${ }^{113}$ These visits ensure that facilities meet the program requirements; they also allow OSHA to secure a great deal of information about workplace safety that it then can use to identify problems at nonparticipating firms. The participating firms, in return, escape from the regular rulebook inspections. In 1993, EPA launched an Environmental Leadership Program (ELP), modeled on OSHA's VPP, which recognized industrial facilities that had delivered exemplary environmental results. ${ }^{114}$ This program, and other EPA programs like it, eventually grew into what the EPA now calls its National Environmental

110 See Voluntary Protection Programs To Supplement Enforcement and To Provide Safe and Healthful Working Conditions, 47 Fed. Reg. 29,025 (Jul. 2, 1982).

${ }^{111}$ See id. at 29,029. Of course, OSHA still reviews worker complaints and accidents and retains its enforcement authority if the site is not meeting its regulatory obligations. See id. at 29,030.

112 See id. at 29,030; see also Michael, supra note 28, at 559-61 (discussing generally the requirements for the program).

113 See 47 Fed. Reg. at 29,030.

${ }^{114}$ See Environmental Leadership Program, 58 Fed. Reg. 4,802 (Jan. 15, 1993). 
Performance Track (NEPT), which recognizes more than 300 facilities across the nation for their environmental excellence. ${ }^{115}$

Facilities that are admitted into OSHA’s VPP and EPA's Performance Track are eligible to join membership associations - the VPP Participants Association and the Performance Track Participants Association, respectively - that have regular meetings with the agencies, benefiting both the industry members and the agencies. Regulators report that that they have learned valuable information from these programs about industry practices and management techniques. ${ }^{116}$ As one EPA official summed up the information value from programs like Performance Track, "We need people we can talk to.”

\section{Nonmandatory Information Requests}

Regulators can ask firms to provide information without offering any rewards or threatening any penalties. OMB estimates that 21.9 percent of authorized information collection requests "are voluntary where a response is entirely discretionary and has no

${ }^{115}$ EPA, National Environmental Performance Track Basic Information, available at http://www.epa.gov/performancetrack/about.htm. Other forerunners to Performance Track included the Strategic Goals Program in the metal finishing sector and the StarTrack program implemented in EPA Region 1.

${ }^{116}$ See David B. Spence, The Shadow of the Rational Polluter: Rethinking the Role of Rational Actor Models in Environmental Law, 89 CAL. L. REV. 917, 955 (2001). 
direct effect on any benefit or privilege for the respondent."117 Undoubtedly, many more such requests are either made without authorization or do not rise to the level where OMB authorization is needed.

Regulators often send voluntary surveys to firms to collect data on regulatory problems, industry conditions, and the financial costs of regulation. For example, the EPA has surveyed regulated water systems about every five years since $1976,{ }^{118}$ collecting information about the current conditions of water systems to help it calculate the costs of drinking water regulations and assess any potential needs for new water quality technologies. ${ }^{119}$ In 2000, the agency surveyed about 1,800 different water systems, mailing surveys to about 1,200 medium and large systems and sending representatives from consulting firms to collect data in person from 600 small systems. The response rate for the small systems was 90 percent, while the rate for all systems was 69 percent. $^{120}$

117 OMB, supra note 77, at 7 (emphasis in original). Even though such requests are technically nonbinding, some firms may perceive that they have little choice but to cooperate. We mean to address here those instances where firms truly do have (and perceive that they have) a choice about whether to disclose, acknowledging that in many cases what looks like a voluntary request may well be tacitly backed up in subtle ways with some threat of punitive response for those who do not participate.

${ }^{118}$ Agency Information Collection Activities: Proposed Collection; Comment Request; Community Water System Survey, 65 FED. REG. 7544 (Feb. 15, 2000) (describing the purpose and design of the survey). ${ }^{119}$ Id. at 7545.

${ }^{120}$ See Community Water System Survey 2000, at http://www.epa.gov/safewater/consumer/cwss_2000_ volume_i.pdf, at p. vi. 
In the late 1980s, OSHA surveyed more than 5,000 companies on the use of personal protective equipment (PPE) in various industrial sectors. ${ }^{121}$ The results enabled OSHA to identify workplace risks, determine the feasibility of new or revised standards, and provide a baseline for assessing the effectiveness of any regulatory changes. ${ }^{122}$ To help ensure the adequacy and accuracy of responses, OSHA conducted the survey by telephone and used strict measures to protect the confidentiality of survey responses. ${ }^{123}$ Regulators can also ask firms to submit to voluntary inspections. Following September 11, 2001, EPA asked several dozen chemical facilities to submit to site visits so the agency could gather information about the adequacy of security practices at chemical facilities, as well as assess security vulnerabilities and identify potential solutions. ${ }^{124}$ EPA currently has little or no legal authority to compel firms to submit to such inspections, but was able to elicit cooperation from a few facilities. The FDA

${ }^{121}$ See Agency Information Collection Activities Under OMB Review; Personal Protective Equipment, Survey, 53 FED. REg. 28,462 (Jul. 28, 1988). Personal protective equipment includes items such as safety goggles and hearing protectors.

${ }^{122} I d$.

${ }^{123}$ Even purely voluntary surveys must still receive approval by the OMB under the Paperwork Reduction Act (PRA) (44 U.S.C. § 3501 et seq). See Jeffrey S. Lubbers, Paperwork Redux: The (Stronger) Paperwork Reduction Act of 1995, 49 Admin L. Rev. 111, 115 (1997). The burden on responding companies with respect to cost and time is one factor that OMB considers when deciding whether to approve information collection requests by agencies.

${ }^{124}$ Robert Westervelt, GAO Calls for National Chemical Security Plan, Chemical Week, March 26, 2003, at 7; Neil Franz, ACC Pushes for Compromise on Security Legislation, Chemical Week, December 18, 2002, at 12; EPA Addresses Chemical Site Security, Slowly, Occupational Hazards, February 2003. 
similarly had no authority to inspect cigarette plants, but once Commissioner Kessler began to take an interest in regulating tobacco, the CEO of Philip Morris agreed to show FDA around one of his company’s facilities. ${ }^{125}$ Until that visit, "no one on the team [developing the FDA rule] had ever been inside a tobacco manufacturing plant.”126 Regulators need to be mindful of when the generalizability of their findings is suspect from surveys or site inspections. While regulations bind all the firms within a sector, firms may be most eager to volunteer information when they are unlike their competitors. Regulators must also worry about the accuracy of self-reported survey results, as firms’ responses may be biased.

\section{E. Formal Interaction}

Formal interaction between industry and regulatory officials provides another mode of gathering information. Formal interaction takes place in public and usually follows a variety of procedural steps. Examples include public hearings, where agency staff sit and listen to testimony from industry, ${ }^{127}$ and the written comments that industry and others

\footnotetext{
${ }^{125}$ KESSLER, supra note 31, at 140-41. Of course, this probably is an example of the situation noted supra, in note 116, where a firm's cooperation was not strictly voluntary. Given the background threat of the FDA regulating tobacco, Philip Morris most likely was using this gesture of voluntary disclosure in an effort to stave off or at least mitigate FDA's regulatory initiative.

${ }^{126}$ Id. at 141 .

${ }^{127}$ Public hearings can take place as part of what is known as "formal rulemaking” under the Administrative Procedure Act, but proceedings that require this on-the-record, trial-type procedure are
} 
submit to the agency during the rulemaking process. ${ }^{128}$ Industry tends to submit the largest proportion of comments in most rulemakings, comments that are filled with extensive data, suggestions, and objections that can sometimes span hundreds of pages (and are undoubtedly mostly self-serving). ${ }^{129}$ All written comments and transcripts from hearings are documented in an agency’s records and are available to the public. ${ }^{130}$

The approximately 1,000 advisory committees established by federal regulatory agencies provide another opportunity for formal interaction. ${ }^{131}$ Congress has recognized

relatively rare. However, public hearings can also be used to provide supplementary input into so-called “informal” or “notice-and-comment” rulemaking. 5 U.S.C. § 553.

128 The drafters of the Administrative Procedure Act, which specifies that agencies provide opportunities for public comment, specifically had in mind that the "the objective should be to assure informed administrative action.” Attorney General's Manual on the Administrative Procedure Act (1947).

${ }^{129}$ See Cary Coglianese, supra note 6, at 741 (noting that "industry groups (i.e., business firms and trade associations) participated the most” in the comment process); WESLEY MAGAT ALAN KRUPNICK, \& Winston HARRINGTON, RULES IN THE MAKING 40 (1986); Marissa Golden, Interest Groups in the Rulemaking Process: Who Participates? Which Voices Get Heard?, 8 J. PuB. Admin. Res. \& TheORY 252, 253 (1998).

${ }^{130}$ Anyone interested in the information must still visit the agency to obtain it, at least for most agencies. A few agencies, like EPA and the Department of Transportation, have begun to post all their comments in Internet-accessible dockets. Within a few years, regulatory comments submitted to all agencies will probably be accessible on-line.

${ }^{131}$ General Services Administration, FACA Database, available at http://fido.gov/facadatabase/default.asp See also General Services Administration, Annual Report of the President on Federal Advisory Committees. The number of advisory bodies is actually larger than the widely cited figure of 1,000 because some advisory committees have distinct subcommittees or other associated working groups. 
that such advisory groups "are frequently a useful and beneficial means of furnishing expert advice, ideas, and diverse opinions.”132 The Federal Aviation Administration (FAA), for example, uses the Aviation Rulemaking Advisory Committee "to obtain direct, firsthand information and insight from the substantially affected interests by meeting together and exchanging ideas with respect to proposed rules and existing rules.”"133 ARAC advises the FAA on most major policy issues, including equipment safety, flight crew training, communication systems, and aircraft noise. The FAA believes this information enables the agency to craft "better rules in less overall time.”"134

In 1994, the EPA established a new advisory committee that met regularly for several years in an effort to identify innovative approaches to environmental regulation across six industrial sectors. ${ }^{135}$ Called the Common Sense Initiative (CSI) Council, the advisory committee included about 30 representatives from industry, trade associations, state and local government, labor, environmental groups, and community organizations. ${ }^{136}$ In

${ }^{132} I d$. at $\S 2$.

133 ARAC Charter.

${ }^{134}$ Id. DOT employs similar committees, with similar objectives, in its other branches, such as the Railroad Safety Advisory Committee (RSAC) used by the Federal Railroad Administration and the Technical Hazardous Liquid Pipeline Safety Standards Committee (THLPSSC) used by the Office of Pipeline Safety.

${ }^{135}$ Common Sense Initiative Council Federal Advisory Committee; Establishment, 59 FED. REG. 55,117

(Nov. 3, 1994).

${ }^{136}$ See David W. Case, The EPA's Environmental Stewardship Initiative: Attempting to Revitalize a Floundering Regulatory Reform Agenda, 50 EMORY L.J. 1, 43 (1993) (discussing generally the CSI program). 
addition, subcommittees were created for each of the six sectors included in CSI: metal finishing, computers and electronics, automobile manufacturing, printing, petroleum refining, and iron and steel. ${ }^{137}$ Although the CSI process did not ultimately lead to major changes in environmental regulation, it did help inform EPA policymakers about technical issues in each of its industrial sectors. ${ }^{138}$ Indeed, much of the activity undertaken in the Common Sense Initiative consisted of research and information collection. ${ }^{139}$

Formal interaction enables regulators to gather information, but the openness associated with these processes can limit the sharing of information. As with gossip in everyday life, information transmission to regulators is more efficient through less formal

${ }^{137}$ See Katherine Bouma, Metal Finishers Try EPA Program, ORLANDO SENTINEL, Jan. 27, 1998 , at A7. ${ }^{138}$ Cary Coglianese \& Laurie Allen, Building Sector-Based Consensus: A Review of the EPA's Common Sense Initiative, in THEO DE BRUIJN \& VICKI NORBERG-BOHM, EDS., INDUSTRIAL TRANSFORMATION (forthcoming). Some observers of consensus-based advisory committees like CSI have argued that these processes help provide regulatory decision makers with better information. See, e.g., Neil Eisner, Regulatory Negotiation: A Real World Experience, 31 FED. BAR N. \& J. 371, 374 (1984) (concluding that a negotiated rulemaking advisory committee established by the FAA resulted in deliberations that "were informative” and that “a better understanding of the problems was developed on all sides”). It far from clear, however, whether information disclosure is significantly increased when advisory committees are charged with reaching a consensus on a regulatory proposal. Cary Coglianese, Assessing the Advocacy of Negotiated Rulemaking, 9 N.Y.U. ENVTL. L. J. 386, 442 (2001) (noting that forms of interaction not organized around consensus provide the same kinds of opportunities for public input and that "it is the deliberation — not the consensus — that generates the information that enables agencies to craft their policy decisions”).

139 Id. at Table 2. 
interaction. Advisory committees, which must include members of competing interests and be open to the public, inhibit frank informational exchange between regulators and industry. ${ }^{140}$ While procedures that promote openness may well help address concerns about illegitimate influence by industry on government policy making, ${ }^{141}$ they can hamper the ability to gather information from industry. ${ }^{142}$

${ }^{140}$ Ashley C. Brown, Sunshine May Cloud Good Decision Making, Forum ApPL. Res. \& PUB. PoL. (1992). The burden associated with establishing FACA committees may also limit the extent to which they are used by regulators. Steven P. Croley \& William F. Funk, The Federal Advisory Committee Act and Good Government, 14 YALE J. ON REG. 451, 549 (1997). Whenever agencies convene a series of ongoing meetings with a group of industry or other nongovernmental representatives, they must follow the requirements of the Federal Advisory Committee Act (FACA). 5 U.S.C. app. 2 § 1-15. The requirements under FACA do not apply to the individual and sporadic meetings with industry that take place most frequently in regulatory policy making. See Croley \& Funk, supra at 453. FACA requires agencies to have balanced committee memberships drawn from different interest groups, that meetings be announced in advance and open to the public, and that the agency take accurate minutes of the committee's proceedings. 5 U.S.C. §§5(b)(2), 10(a)(3), \& 10(c). For example, OMB must approve all new proposals for advisory committees. Management of Federal Advisory Committees, O.M.B. Circ. No. A-135 (Oct. 5, 1994). OMB has also established ceilings for the number of advisory committees. Id.

${ }^{141}$ Croley \& Funk, supra note 139, at 453 (noting that in enacting FACA Congress’s attempted to address concerns that "some interests had come to enjoy unchecked and perhaps illicit access to federal executive decisionmakers.”).

${ }^{142}$ See infra Part IV. 


\section{F. Informal Interaction}

Informal interaction, which is not nearly as visible as formal exchange, is a staple of regulatory life. ${ }^{143}$ It often takes place by telephone. In a recent rulemaking proceeding on motorcycle brake systems, a staff member at NHTSA called up a representative at the motorcycle trade association to learn more about the effect of temperature on the friction between brake linings and discs. ${ }^{144}$ Informal communication also takes place in person, in meetings regulators hold with individual representatives from industry, and in working groups of such representatives arranged so that they skirt the requirements of the Federal Advisory Committee Act. ${ }^{145}$ Regulators interact with industry at professional meetings,

${ }^{143}$ Over fifty percent of the Washington interest groups surveyed by Neil Kerwin and Scott Furlong reported that government proactively initiated contact with their organizations "on a regular basis." Cornelius Kerwin, Rulemaking: How Government Agencies Write LaW And MaKe Policy 189 (3d ed. 2003). According to Kerwin, “a common reason for these contacts is to get information for the rule under development.” Id. See also Home Box Office v. Federal Communications Commission, 567 F. 2d 9, 57 (D.C. Cir. 1977) (describing “informal contacts between agencies and the public [as] the 'bread and butter' of the process of administration”).

${ }^{144}$ Memorandum of George Soodoo, Division Leader, National Highway Traffic Safety Administration, Docket NHTSA-99-6472-7 (June 18, 2001).

145 FACA does not apply to all meetings between regulators and industry. For example, agency officials are permitted to meet alone with an individual, because an individual cannot be a committee. See 41 C.F.R. $\S 101-6.1004(\mathrm{~h})$ (meeting initiated by President or agency to seek advice from single individual not subject to FACA). Moreover, the General Services Administration (GSA), which has been charged with implementing FACA throughout the federal government, explicitly excludes from its definition of advisory committee any meeting where "the purpose is the exchanging of facts or information" as opposed to giving 
academic conferences, and wherever both industry and government representatives are present. $^{146}$

Government regulators and industry representatives often develop relationships over periods of years, or even decades, and will work closely with each other on the development of regulations. ${ }^{147}$ As one EPA staff member explained:

We try to bring them in as early as possible on what we are required to do and request their help very early on. And usually this is appreciated because that way they have input as opposed to EPA unilaterally going out and looking at various textbooks and writing rules that are ridiculous because we don't fully advice or making recommendation. 41 C.F.R. § 101-6.1004(l). See also 5 U.S.C. § 3(2) (defining an advisory committee as one that is "established or utilized...in the interest of obtaining advice or recommendations”). But see Croley \& Funk, supra note 139, at 488 (questioning GSA's interpretation). Even meetings where advice is given can be excluded from FACA if the advice is given individually by participants, as opposed to meetings that lead to collective recommendations. See Croley \& Funk, supra note 139, at 474; 41 C.F.R. § 101-6.1004(i). Finally, to fall under FACA, meetings need to be held more than once, so ad hoc or one-time meetings generally do not need to meet FACA's requirements. See Croley \& Funk, supra note 139, at 483-84.

${ }^{146}$ Coglianese, supra note 6, at 750. An excellent example of a setting that was specifically designed to promote such informal interaction is the Harvard Electricity Policy Group (HEPG), established by our colleague, Professor William Hogan. HEPG brings together representatives from industry, government, academe, and environmental groups for discussions aimed at “informing and analyzing” policy development. Harvard Electricity Policy Group, Reshaping the Electricity Industry: A Public Policy Debate (June 2001).

147 See, e.g., Errol Meidinger, Regulatory Culture: A Theoretical Outline, L \& PoL. (1987). 
understand what the hell we are regulating. So it works out better by working very closely with the people that we are going to regulate and we do this in various ways. We meet with them; we have industry-agency workgroups that will meet together. ${ }^{148}$

Another EPA staff member expressed the same thought: “The more information [industry] can help us with, the better the rule will turn out - in their interest as well as everyone else’s.”"149

Industry representatives in Washington also seek out information from regulators and try to learn of opportunities to influence the shape of regulatory policy. ${ }^{150}$ As one corporate vice-president for regulatory affairs remarked:

Our Washington office - they know the regulators down in the bowels of the agency personally. They are over there all the time, they’ve become friends with them, they supply data and assist them in any way that it's legitimate to do. So we have open communications constantly about what they're thinking, what

\footnotetext{
$\overline{148}$ Coglianese, supra note 6, at 751.

${ }^{149} I d$.

150 Political scientists who study the role of interest groups in policy making have long acknowledged that lobbyists traffic in information. See Lewis Anthony DeXter, How OrganizATIONS ARE REPRESENTED IN WASHINGTON 130 (1969) (“The effective Washington representative provides influence for his client by acquiring and translating relevant information.”).
} 
we'd like them to do, what we think they're gonna do. It's almost like

becoming joined at the hip with the staff over there. ${ }^{151}$

In this way, informal interaction serves industry's interests as well as government's needs, which means that regulators are in a position to offer information about their plans to industry in exchange for industry providing government with information. ${ }^{152}$

While in formal regulatory proceedings conducted through a trial-type hearing, such so-called ex parte communications are prohibited under $\S 557(d)(1)$ of the Administrative Procedure Act, there is no corresponding provision for ex parte communications during informal or notice-and-comment rulemaking. The D.C. Circuit Court of Appeals’ controversial decision in Home Box Office, Inc. v. FCC, ${ }^{153}$ although construed narrowly by subsequent courts, ${ }^{154}$ has been reinforced by agency policies

${ }^{151}$ Coglianese, supra note 6, at 751.

${ }^{152}$ Id. at 750 (noting that "informational dependence ... lead[s] interest group representatives and agency staff to find themselves engaged in ongoing and often mutually beneficial relationships”).

${ }^{153} 567$ F.2d 9, 57 (D.C. Cir. 1977) ("If ex parte contacts [occur after the issuance of a notice of proposed rulemaking], we think that any written document or a summary of any oral communication must be placed in the public file established for each rulemaking docket immediately after the communication is received so that interested parties may comment thereon.”); see also id. (“[C]ommunications which are received prior to issuance of a formal notice of rulemaking do not, in general, have to be put in a public file.”).

${ }^{154}$ United Steelworkers of America v. Marshall, 647 F.2d 1189 (D.C. Cir. 1980), cert. denied 453 U.S. 913 (1981) (declining to apply ex parte requirement in Home Box Office to OSHA notice-and-comment rulemaking); Sierra Club v. Costle, 657 F.2d 298 (D.C. Cir. 1981) (declining to follow Home Box Office requirement in EPA notice-and-comment rulemaking). 
requiring the documentation of informal contacts that take place after the publication of a notice of proposed rulemaking. ${ }^{155}$ Even though some agencies require their staff to document all ex parte communications whenever they occur; it is extremely difficult to ensure that staff members comply fully with these requirements. In addition, the memoranda that agency staff members prepare to describe their ex parte communications are often quite brief and general. Since the informal communications frequently involve contact with only a single agency staff member, there is often no way to know for sure whether documentation of ex parte communications is complete. The upshot is that informal contacts with industry continue to take place largely below the radar, especially prior to the filing of a notice of proposed rulemaking. ${ }^{156}$

One additional pattern of interaction deserves mention: the so-called "revolving door." ${ }^{\text {157 }}$ When regulators move from government into jobs within industry, this facilitates future informal contacts between the regulatory agency and relevant firms or trade associations. When people move from industry into government, this facilitates informal contacts and brings insider's knowledge about an industry into a regulatory

155 See, e.g., Department of Transportation Order No. 2100.2 (1970) (requiring prompt and public documentation of ex parte communications after the publication of the notice of proposed rulemaking); Environmental Protection Agency, Administrator’s Memorandum of May 31, 1985 (requiring agency staff to place in the docket "a memorandum summarizing any significant new factual data or information likely to affect the final decision received during a meeting or other conversations”).

${ }^{156}$ Cf. Coglianese, supra note 6, at 75 ("In the rule development phase, industry groups tend to dominate because of the information they can provide to the agency staff as they write a rule.”).

157 See, e.g., William T. Gormley, Jr., A Test of the Revolving Door Hypothesis at the FCC, 23 AMER. J. POL. SCI. 665 (1979). 
agency. FDA Commissioner David Kessler made sure to include on the cigarette regulation project an FDA staff member who had previously worked for "the other side" - the tobacco industry. ${ }^{158}$

\section{The Implications of Information Gathering}

How can regulators best use the information-gathering tactics at their disposal to gather reliable information from firms that would prefer to remain silent? In this Part, we connect the information-gathering tactics presented in Part III with the general informational strategy developed in Part II, emphasizing the strategic advantages of informal interactions with industry. These advantages lead to some striking implications for administrative law, which we explain in the final section. For at least the past three decades, administrative law has promoted greater procedural transparency of government decision making to discourage regulatory capture and other special deals between regulators and the firms they regulate. ${ }^{159}$ However, the potential adverse impacts of transparency and formalism on government's ability to collect essential information from industry have been generally overlooked.

\footnotetext{
158 KESSLER, supra note 31, at 125.

${ }^{159}$ See infra notes $185-92$ and accompanying text.
} 


\section{A. Connecting Tactics with Strategies}

Which of the various information-gathering tactics exploit asymmetries of interests across or within firms, and which create incentives for disclosure? Some of the tactics clearly match up with regulators' two basic strategies. Issuing subpoenas and rewarding disclosure are obvious ways to create incentives. Nonmandatory requests for information clearly seek to exploit asymmetries of interest, as the firms or facilities that open themselves up to voluntary inspection by the regulator, or that voluntarily respond to information requests, presumably have an interest in being forthright with the regulator. $^{160}$

The connection between strategy and the other tactics may seem less clear, at least at first glance. Making regulatory decisions contingent on disclosure might appear to reward firms for disclosing information, since firms only obtain their license or regulatory approval after they have provided the regulator with information. But in fact, firms are rewarded only for disclosing a certain kind of information -- information favorable to the firm -- not when they disclose adverse information showing their products or drugs are unsafe. The cases of fraud in FDA applications for new drugs indicate that the tactic of conditioning approval on disclosure does not really help the

\footnotetext{
${ }^{160}$ Moreover, the fact that surveys or inspections are treated confidentially means that participating firms can usually transmit information without fear of any reprisals from others in their industry. In some cases, others will know that the agency is asking for information, but they will generally never be able to identify what information has actually been conveyed or by whom.
} 
regulator obtain information that most industrial players would prefer it not to have. ${ }^{161}$ Linking approval to disclosure exacerbates industry's predisposition to disclose selfserving information.

Conditioning decisions on disclosure works best when firms' disclosure interests are asymmetric - say if the information that helps one firm win regulatory approval also helps the regulator in regulating other firms in the future, on the same or some other issue. When the FDA relied on information submitted with tobacco company patent applications, it actually exploited an asymmetry in interest that cut across time. ${ }^{162}$ When they submitted patent applications, tobacco companies had an interest in disclosing information about their ability to manipulate nicotine to the Patent Office; they may not have even envisioned that a different regulator, the FDA, would later use that information against them in trying to regulate cigarettes. Similarly, in large, compartmentalized organizations, individuals in one office may release certain information when applying for regulatory approvals falling within their domain, overlooking or underestimating the negative implications for future policy making or on regulatory matters outside their purview.

The tactic of formal interaction serves neither of the regulators' main strategies very well. It generally places regulators in a relatively passive role in which they receive information but do not actively seek it. While information is obviously transmitted in public hearings and formal comment periods, it is only information that the parties want them to receive, not necessarily the information that regulators most need. As with

\footnotetext{
${ }^{161}$ See supra note 80 and accompanying text.

${ }^{162}$ See supra note 85 and accompanying text.
} 
respondents to nonmandatory requests for information, those who attend hearings or take the time to file comments are a self-selected group of interested parties. Moreover, unlike nonmandatory requests, formal modes of interaction such as hearings and comment processes are open-ended, so the regulator often cannot effectively direct the subject matter of the inquiry. It is hard to see how regulators could use such passive modes to exploit asymmetric incentives or create new ones. ${ }^{163}$

Other types of formal interaction, such as advisory committees, may better enable regulators to exploit asymmetries or create incentives for firms to reveal adverse information. Since membership on an advisory committee can reward firms by giving them greater access to the agency, the ability to appoint members to these committees in principle allows regulators to reward firms that have a track record of providing reliable and useful information. However, a variety of factors constrain the effectiveness of advisory committees. Once a committee is constituted, regulators have little opportunity within the confines of the formal process to reward firms that reveal needed information during committee deliberations. Any “deals” that the regulator might like to make with individuals firms are inhibited by the transparency of the advisory committee process. Moreover, advisory committees must represent a balanced collection of members, so that

\footnotetext{
${ }^{163}$ See John Applegate, Beyond the Usual Suspects: The Use of Citizen Advisory Boards in Environmental Decisionmaking, 73 IND. L.J. 901 (1998) ("While procedures like public hearings can be a good opportunity for many people to hear presentations, to express their views, and perhaps to engage in question-and-answer sessions, they cannot provide the forum for extensive development of information.”).
} 
regulators cannot merely appoint members from firms that reveal information. ${ }^{164}$ Most important, the requirement that advisory committee deliberations remain open to the public means that any firm's decision to break an industry's collective silence would be known to those who could punish that firm. ${ }^{165}$ For these reasons, advisory committees do not provide regulators with a powerful tool for breaking industry silence. Surely the FDA never would have gathered much information for its cigarette rulemaking by appointing tobacco representatives to an advisory committee.

The chief contribution of advisory committees may be, ironically, to facilitate informal interactions. Even though regulators may not learn much from the formal meetings of advisory committees, these sessions do give regulators and industry representatives opportunities to get to know each other and build relationships that can lead to productive informal interaction. In many cases, the most valuable

16441 C.F.R. §101-6.1007 (requiring agency plan to ensure that the agency strives "to attain fairly balanced membership”). Of course, some advisory committees will be more wide-ranging than others, just given the make-up of the interest group community around the issue. On those issues that are relatively obscure or technical, and where the interest group universe is relatively tight, it might be possible for regulators to choose precisely the actors most likely to disclose. On issues where there is a broader and more conflicted range of interests, this will be harder to achieve.

1655 U.S.C. §10. To be sure, agencies can always interact with the members of advisory committees on an individual basis, outside of the open committee process. In some cases, regulators may use the formal process as a vehicle for forging closer relationships with potential sources of information who the regulators then approach individually and informally outside of the advisory committee process. For further discussion of using a mixture of tactics for securing information, see infra Part II.D. 
communications among members of advisory committees take place in the hallways before or after the formal meetings or during breaks. ${ }^{166}$

Informal interaction provides excellent opportunities for regulators to use both information-gathering strategies. They can telephone those whom they believe are more disposed to talk - and reward firms that participate through informal trades. The quid pro quos can consist of information from the agency or potentially desirable treatment in regulatory action. Agencies can also informally punish firms that refuse to disclose information by reducing access to the agency or subtly slowing the agency's responsiveness on other matters to those. We develop the virtues of informal interaction more fully in the next section. ${ }^{167}$

To summarize, Table 1 shows the connections between the basic informational strategies and the six main tactics. To create incentives for disclosure, the best tactics are (1) mandating disclosure, (2) creating rewards for disclosure (such as by establishing recognition programs like EPA’s Performance Track), and (3) engaging in more subtle manipulation of interests through informal interaction. When regulators seek to exploit asymmetries, they should (1) issue nonmandatory requests and take advantage of the information provided by volunteers, or (2) seek firms more inclined to disclose through informal (and hence more hidden) interaction. Relying on information provided in licensing or other approval processes where decisions are conditioned on disclosure will

\footnotetext{
${ }^{166}$ See Ellen Siegler, Regulatory Negotiations: A Practical Perspective, 22 EnVTL. L. ReP. (ENVTL. L. INST.) 10,647, 10,648-49 (Oct. 1992) (observing from personal experience that extensive communication takes place outside of the public sessions of negotiated rulemaking advisory committees).

167 See infra notes 165-76 and accompanying text.
} 
generally only help for policy issues that are more tangentially related to the approval processes. Finally, formal interaction, though perhaps serving purposes other than information acquisition, generally will not effectively advance either strategy for gathering adverse information.

\section{Table 1. Potential Contributions of Information Tactics to Strategies}

\begin{tabular}{|l|c|c|}
\cline { 2 - 3 } \multicolumn{1}{c|}{} & \multicolumn{2}{c|}{ Strategy } \\
\cline { 2 - 3 } \multicolumn{1}{c|}{ Tactic } & $\begin{array}{c}\text { Exploit } \\
\text { Asymmetries }\end{array}$ & $\begin{array}{c}\text { Create } \\
\text { Incentives }\end{array}$ \\
\hline Contingent Decisions & Medium & Low \\
\hline Mandated Disclosure & Low & High \\
\hline Rewards and Recognition & Low & High \\
\hline Nonmandatory Requests & High & Low \\
\hline Formal Interaction & Medium & Low \\
\hline Informal Interaction & High & High \\
\hline
\end{tabular}

\section{B. The Virtues of Informality}

Throughout the world, proponents of good government favor increased transparency (and thus usually formality) in regulatory decision making. ${ }^{168}$ Informality is often viewed as suspect by reviewing courts and others who fear that government's informal

168 ORganization fOR ECONOMic Co-Operation AND Development, The OECD Report ON REGULATORY REFORM: SYNTHESIS (1997) (noting that “[l]ack of transparency is a key problem” in OECD countries). See also OrganizATION FOR ECONOMic Co-OPERATION AND DEVELOPMENT, STRENGTHENing Regulatory Transparency: Insights FOR the GATS From the REgulatory ReFORM COUNTRY REVIEWS, OECD TD/TC/WP (99)43/FINAL (April 12, 2000) (discussing the importance of transparency in domestic regulatory systems). 
interaction with industry will result in regulatory policies that favor industry over the broader interests of society. ${ }^{169}$ Yet from the standpoint of information collection, these fears are misplaced: industry will not hesitate to provide the government with the kind of information that would support policies that favor industry, whether the process is formal or informal. ${ }^{170}$ To obtain information needed to advance society's interests at the expense of industry interests, in those cases where this is desirable, regulators must exploit or create different interests in disclosure, strategies that are actually made more cumbersome by formal, transparent processes. Whatever the drawbacks to informality, it possesses distinct advantages for extracting adverse information. ${ }^{171}$

169 See, e.g., Elena Kagan, Presidential Administration, 114 HARV. L. REV. 2245, 2267 (noting that interaction taking place in "informal and nontransparent ways" has led to "concerns about inequalities of interest group access and resulting agency capture.”); Richard Stewart, The Reformation of American Administrative Law, 88 HARV. L. REV. 1669 (1975) (noting that because "bias in agency policies is often attributed to informal decisions, courts have imposed requirements that force agencies to adopt formal procedures”).

${ }^{170}$ Of course, the concern may less with information than with firms using informality to offer explicit or implicit bribes to government officials. We discuss implicit trades for information in more detail in Part IV.D.

${ }^{171}$ See Kerwin, Rulemaking, supra note 142, at 192 (noting that "informal mechanisms and difficult-toobserve mechanisms for communicating views to agencies are used a great deal and are thought to be as or more effective than traditional means - such as written comment - that figure so prominently in the procedural law and academic literature on rulemaking”); Sierra Club v. Costle, 657 F2d at 401 (“Informal contacts may enable to the agency to ... spur the provision of information which the agency needs.”). 
Informal interaction enables regulators to be more proactive and nimble in their efforts to gather information, partly due to the lower costs associated with informality. ${ }^{172}$ It is very easy to pick up the phone and call a contact in industry. It is also usually less costly to craft and calibrate incentives when proceeding informally. Simply failing to return a phone call or to invite a trade association representative to an important meeting are cheap ways to punish an uncooperative firm. Returning phone calls, sharing information about agency initiatives, or involving industry in key meetings are cheap ways to reward cooperative firms. ${ }^{173}$

Informality also preserves the regulator's discretion and protects the privacy of communications, allowing regulators to target discretely those firms that are more likely to disclose. Information disclosure is less visible when it is informal, so that informants who break industry's collective silence can be better protected against retribution. The opaque nature of informal interaction allows regulators to create incentives for disclosure without being accused of having created special deals, which they are in fact making, or of having treated firms unfairly by punishing them for failing to share information. ${ }^{174}$

172 See supra notes 142-69 and accompanying text.

173 These rewards and punishments may seem insignificant, but to firms in heavily regulated industries, the loss of reciprocal cooperation can be quite significant. These players know that even though they may make strenuous substantive objections to agency proposals, it is not in their interest to play hardball with regulatory staff. Coglianese, supra note 6.

${ }^{174}$ Making the case for punishing nondisclosure is usually difficult. After all, if a firm failed to disclose information, is that because there was nothing to disclose or because the firm was uncooperative? See supra note 110-111 and accompanying text. Since the "crime" of nondisclosure or inadequate disclosure 
Regulators and industry representatives who interact with each other repeatedly will tacitly understand the incentives that regulators create informally, but these same incentives will often be nearly invisible to others.

The opaque nature of informal interaction helps to preserve deniability. Though deniability can be used to hide actions that are illegal or inconsistent with the public interest, it is also extremely helpful for whistleblowers, firms that volunteer information adverse to others in their industry, and public-interested regulators who need to make deals to gain needed information. The pressures that work against the revelation of adverse information can be significant, so the ability to communicate confidentially increases the likelihood that some socially valuable information will be transmitted.

Deniability is especially important for representatives of trade associations, who often negotiate with both the agency and the managers and firms that they represent. ${ }^{175}$ In order to win the favor of regulators, trade association representatives will sometimes provide information off the record, such as about industry's general "bottom line." Individual lobbyists sometimes privately tell regulators that their industry will not resist a specific policy provision, even as they maintain a public posture of resistance. As with leaks of government information to the press, those who provide the information to the government often need to preserve deniability for what they have disclosed.

seldom has its corpus delecti (dead body), regulators' efforts at punishment for nondisclosure will often be susceptible to charges of unfairness.

${ }^{175}$ Cary Coglianese, Unequal Representation: Membership Input and Interest Group Decisions (unpublished manuscript), available at http://www.ksg.harvard.edu/prg/cary/unequal.htm. 
Much more than with formal interaction, informal interaction allows government to derive information from the behavior of firms, not just from what they say. Regulators draw inferences about the intensity of different firms' interests from the extent of their involvement on specific regulatory issues. ${ }^{176}$ Such intensities are better uncovered by informal processes, in which firms choose their own level of participation, than in formal processes which - due to their focus on fairness -tend to foster equal levels of participation.

Extensive and active resistance to a regulation suggests that an industry, or the firms within it, have information that the regulation will impose high compliance costs. ${ }^{177}$ Firms will overstate these costs, but reveal their intensity through their observable lobbying efforts. ${ }^{178}$ Moreover, when informal relationships with government are ongoing, firms are more constrained in their ability to overstate - they cannot repeatedly threaten that they are going to close down in the face of regulatory action without losing credibility.

For these reasons, regulators should rely on informal tactics before resorting to formal ones. Even when they are insufficient, informal tactics can inform regulators' use of

\footnotetext{
${ }^{176}$ Richard L. HALl, PARTicipation In CONGRess 3, 7, 237 (1996) (discussing the role of intensities of interests).

177 See Johnston, supra note 12.

178 Regulators do not need to see the lobbyists' actual expenditures to draw these inferences, as has sometimes been suggested. Matthew D. Adler, The Positive Political Theory of Cost-Benefit Analysis: A Comment on Johnston, 150 U. PENN. L. REV. 1429, 1442-43 (2002). Instead, regulators can gauge a firm's relative level of interest by comparing its lobbying on one issue with its lobbying on other issues -- or with lobbying by other firms of comparable size on other issues.
} 
other tactics, such as issuing subpoenas. To issue effective mandatory information requests, regulators need to know what to ask, and informal, off-the-record conversations can point the way. For example, New York Attorney General Eliot Spitzer took advantage of informal tips provided by industry insiders to lay the groundwork for several formal investigations of financial markets by his office and the Securities and Exchange Commission. ${ }^{179}$

\section{Discerning Truth from a Position of Ignorance}

Information collection is ultimately about finding truth. How do regulators judge whether they have obtained accurate information? As former FDA Commissioner David Kessler has commented, "Because we did not understand exactly what we were looking for, we did not know how to press the company for more information. And when the company gave us answers, we had no way to challenge them."180 While this problem can never be fully overcome, it can be addressed in two ways.

179 See, e.g., Abigail Rayner, Ten-Minute Call Sparked Inquiry, The Times, Dec. 10,. 2003, at 33. The charges filed against Putnam Investments for market timing followed a tip-off by an employee at a Putnam call-center to Massachusetts’ regulators. John Hechinger, How One Call Taker Spurred the Putnam Mutual-Fund Case, The Wall Street Journal, Oct. 28, 2003, at C1.

${ }^{180}$ KESSLER, supra note 31, 182 (2001). This problem is compounded when, as happens on many important regulatory issues, regulators actually have before them an abundance of bits of data given to them by industry, for they need to know which of these bits are accurate and relevant. This is why, earlier in this article, in defining the problem of collective "silence," we made a point to acknowledge that we were making a simplifying assumption in treating disclosure as a binary choice. See infra note 41 and 
The first is to draw upon multiple sources of information. (Social scientists call this triangulation.) ${ }^{181}$ If different sources and methods generate reasonably consistent answers, then regulators can have greater confidence in the accuracy of the information. ${ }^{182}$ If the information proves inconsistent, regulators must consider the interests of those providing information and their reputations for credibility.

When regulators routinely seek out multiple sources of information, firms have an added incentive to be honest, knowing that others will provide a check on what they

accompanying text. Even if this assumption were to be relaxed, the problem we have elucidated in this article remains basically the same. The collective silence problem we have addressed here is not necessarily a problem of getting industry to say something at all, but rather of getting them to say something accurate when doing so would ordinarily be against their interests.

181 Alan Bryman, Triangulation, in Michael Lewis-BeCK ET AL., EDS., EnCYCLOPEDIA OF SoCiAL SCIENCE RESEARCH METHODS (forthcoming), available at http://www.referenceworld.com/sage/socialscience/triangulation.pdf.

${ }^{182}$ If the information is not consistent, regulators should consider the interests of those providing the information and their reputations for credibility. If some firms provide data showing that a regulation will be extremely costly, but other similar firms in the same industry provide data showing that it will not be as costly, regulators might appropriately discount the data provided by the first set of firms, as claims of high compliance costs are self-serving. The claims by firms reporting lower compliance costs will be properly viewed as more credible, all other things being equal. On the other hand, if industry reports that compliance costs will be high but consumer or environmental activists provide information indicating that the costs will be low, then without anything further regulators will be unable to adjudicate between the two claims, since the information provided by consumer groups would also be self-serving. 
say. ${ }^{183}$ In addition, the more sources the regulator approaches, the more likely one or more will squeal. Not surprisingly, regulators and former regulators have told us that they gather information by pursuing many different avenues, seeking information from multiple sources. They vet information gathered from one source with other sources; use information obtained through one tactic to bolster and refine other tactics; and sometimes bring parties with disparate interests together to test competing claims in informal, adversarial meetings. ${ }^{184}$

Regulators can also improve the reliability of information by fostering closer and longer relationships with industry. While close, ongoing relationships between regulators and industry have long been deplored, often characterized pejoratively as “cozy iron triangles, ${ }^{185}$ they also allow regulators and representatives from industry to learn to cooperate with each other and gain a basis for establishing credibility and trust. ${ }^{186}$ A firm

183 This can also serve as a check on any "groupthink” bias that might emerge over time in government's ongoing relationships with industry.

${ }^{184}$ David Kessler's account of the FDA's efforts to regulate cigarettes is a good illustration of how an agency deploys multiple tactics and tries to triangulate. KESSLER, supra note 31.

185 Douglas CATER, POWER IN WAShington (1964). The more neutral terms are “issue networks” and “regulatory cultures.” Hugh Heclo, Issue Networks and the Executive Establishment, in ANTHONY KING, ED., The New American Political System (1978); Thomas L Gais et al., Interest Groups, Iron Triangles, and Representative Institutions in American National Government, 14 BRIT. J. POL. SCI. 161185 (1984); Mark A. Peterson, Political Influence in the 1990s: From Iron Triangles to Policy Networks, 18 J. HeAlth Pol., POL. \& L. 395 (1993); Meidinger, supra note 146.

${ }^{186}$ See Coglianese, supra note 6, at 749-53. Interestingly, the original work on the evolution of cooperation came from an analysis of iterated play of the prisoner's dilemma, a game that in its original formulation is 
may wish to distort information given to the regulator in any given round of the regulatory game, but if the regulator uncovers a deception it can retaliate against the firm (albeit perhaps in subtle ways) in later rounds. For heavily regulated industries, regulators are civil servants who tend to remain in their positions for a long time; hence, the shadow of the future will be long. ${ }^{187}$

\section{Implications for Administrative Law}

For at least the past half-century, social scientists and legal scholars have viewed closeness between regulators and industry as a matter of concern, a problem to overcome through the design of administrative law. ${ }^{188}$ Closeness has implied influence and bias, the risk of regulatory capture, and the creation of regulatory policy that systematically favors the interests of industry. ${ }^{189}$ As a result, administrative law has through the years

really all about the disclosure of information. See AxELROD, supra note 100; Parson, Zeckhauser \& Coglianese, supra note 7.

${ }^{187}$ See Coglianese, supra note 6, at 753.

188 See, e.g., TheOdore J. Lowi, The End of Liberalism: The Second Republic of THE United StATES (1979); Richard Stewart, The Reformation of American Administrative Law, 88 HARV. L. REV. 1669 (1975).

${ }^{189}$ Mark Seidenfeld, A Civic Republican Justification for the Administrative State, 105 HARV. L. REV. 1511, 1565 (1992) (“According to the capture hypothesis, instead of providing meaningful input into deliberation about the public interest, industry representatives co-opt governmental regulatory power in order to satisfy their private desires.”). 
aimed to make the regulatory process more transparent, with little concern for the regulator's information deficit. ${ }^{190}$

Congress has pronounced that it is "the policy of the United States that the public is entitled to the fullest practicable information regarding the decisionmaking processes of the Federal Government.”191 This general commitment runs throughout administrative law. For example, the Freedom of Information Act (FOIA) establishes a presumption

190 Slater Steels Corp. v. United States, 279 F. Supp. 2d 1370, 1379 (Ct. Intl. Trade 2003) (“Agency transparency is a cornerstone of administrative law.”); Alfred C. Aman, Jr., Globalization, Democracy, and the Need for a New Administrative Law, 10 InD. J. GLOBAL LEG. STUD. 125, 147 (2003) (“Administrative law has always been grounded upon basic norms. These norms include transparency, participation, and fairness.”); Martin Shapiro, Administrative Law Unbounded: Reflections on Government and Governance, 8 IND. J. GLOB. L. STUD. 369, 376 (2001) (“[A] fascination with transparency and participation remains central to administrative law”); (Cary Coglianese, Administrative Law, in PAul B. BALtes \& NeIL J. SMELSER, EDS., 1 INTERNATIONAL ENCYCLOPEDIA OF SOCIAL AND BEHAVIORAL SCIENCES 85-88 (2001) (“Transparent procedures and opportunities for public input give organized interests an ability to represent themselves, and their constituencies, in the administrative process.... These procedures may also protect against regulatory capture.”); Thomas W. Merrill, Capture Theory and the Courts: 1967-1983, 72 CHI.KENT. L. REV. 1039 (1997) (noting the judicial thrust toward "changing the procedural rules that govern agency decisionmaking [to] force agencies to open their doors -- and their minds - to formerly unrepresented points of view, with the result that capture would be eliminated or at least reduced”); Home Box Office v. Fed. Commn. Comm., 567 F.2d 9, 57 (1977) (“Secrecy [is inconsistent] with fundamental notions of fairness implicit in due process and with the ideal of reasoned decisionmaking on the merits which undergirds all of our administrative law.”).

${ }^{191}$ Government in Sunshine Act, Pub. L. 94-40, § 2 (1976) (preamble). 
that government records will be accessible to the public. ${ }^{192}$ The Government in Sunshine Act and the Federal Advisory Committee Act require that critical regulatory meetings be announced in advance and made open to the public. ${ }^{193}$ Regulators are expected to document ex parte communications that occur after the publication of a notice of proposed rulemaking. ${ }^{194}$ In addition, regulators must provide reasons for their policies and must base their decisions on an administrative record that is available to the public as well as to courts and members of Congress. ${ }^{195}$

These rules aim to prevent abuses and systematic bias, which are genuine concerns. ${ }^{196}$ Nevertheless, they also hobble the ability of well-intentioned regulators to secure the reliable information they need to make better decisions. Administrative law developments that make the regulatory process more transparent dampen the leverage the regulator has over industry in the information game. For example, under the Regulatory

1925 U.S.C. $\S 552$.

${ }^{193} 5$ U.S.C. §552b; 5 U.S.C. App. 2.

194 See supra notes 152-54 and accompanying text.

195 Motor Vehicle Manufacturers Assn. v. State Farm Mut. Auto. Insur. Co., 463 U.S. 29 (1983). The presumption of judicial review combined with the establishment of executive and legislative oversight embeds regulatory policy making within a constitutional system of checks and balances designed to keep decision-making from being based on a narrow set of interests or factions. Cass Sunstein, Factions, SelfInterest, and the APA: Four Lessons Since 1946, 72 VIRG. L. REV. 271 (1986); Seidenfeld, supra note 186. 196 Mock, supra note 39, at 1092 ("Transparency about government operations and the finances of government officials is a primary means of deterring corruption and of uncovering it when it occurs.”); see also id. at 1094 (“[T]ransparency has value in preventing and revealing rent-seeking”); id. at 1100 
Flexibility Act, agencies must publish information twice a year about all the regulations it has in development, ${ }^{197}$ and FOIA obligates agencies to disclose internal agency documents whenever industry requests them. ${ }^{198}$ These laws weaken the regulator's position vis-à-vis industry in the information game, even though they do serve important values in a democracy. In the absence of these laws, regulators could be more selective about sharing such information, providing it more readily to those who in return provide the agency with information it needs. ${ }^{199}$

Transparency can also undercut the regulator's ability to elicit information from firms that might fear retribution. Regulators do not want to risk exposing their best sources of information within industry, any more than those who work for national security and intelligence agencies want to risk exposing their sources. A bit of opacity protects the privacy of sources, and may allow firms or their representatives to be more forthcoming and honest about sharing adverse information.

(“[T]ransparency is coming to be recognized as essential to good governance and to establishment of the rule of law within ordered societies.”).

1975 U.S.C. §§601-612 (1994 and Supp. III 1997).

198 U U.S.C. $\S 552$.

${ }^{199}$ Of course, even with these laws, agencies still may be able to trade on the slippage between the law on the books and the law in action. They may, for example, be able to trade on more fine-grained information about the agency that cannot be obtained in any way other than through information trades. Moreover, just as mandatory disclosure is a limited tool for regulators, the mandatory disclosure requirements imposed upon agencies may be limited for outside groups that really want to know what is going on within the agency. This is why large and sophisticated industry players still acknowledge an advantage to becoming “joined at the hip” with the regulatory agency. See supra note 150 and accompanying text. 
Requiring complete transparency about virtually every conversation in government, though perhaps now technologically possible, would make regulators' jobs much more difficult. What is needed is neither total transparency nor total opacity, but rather a mix that mitigates the risk of regulatory bias, whether from cognitive bias or outright corruption, and preserves some room for regulators to interact privately with industry in order to pry open industry's collective silence.

Despite administrative law's overall trend toward transparency, a few procedural features still leave some room for regulators to play the information game. For example, agency procedures, as well as the D.C. Circuit Court's decision in Home Box Office, do not prohibit ex parte communications altogether, nor do they generally require agency staff members to document all of their ex parte communications. ${ }^{200}$ Rather, they only require documentation of those communications taking place after the agency issues a proposed rule. ${ }^{201}$ Not surprisingly, interest groups have come to engage in extensive informal communication with regulators before any proposed rules are announced. ${ }^{202}$

Even FOIA preserves some protection for the privacy of business information by exempting certain types of records from required disclosure, including national security documents, personnel records, and trade secrets or other confidential business information. ${ }^{203}$ Significantly, the D.C. Circuit, concerned with the impact of disclosure on future government efforts to secure information, has held that FOIA requires

\footnotetext{
${ }^{200}$ See supra notes 152-54.

${ }^{201} I d$.

202 KeRWIN, supra note 142, at 188.

2035 U.S.C. §552(b).
} 
additional protection for confidential business information that industry voluntarily provides to government. ${ }^{204}$ Congress has also recently added new protections against disclosure under FOIA for confidential information provided voluntarily by industry on “critical infrastructure,” such as telecommunications, energy, financial, and transportation systems. ${ }^{205}$ These measures strike a balance between openness and government's need to protect industry's confidential exchange of information with government regulators. ${ }^{206}$ Against administrative law's overall march toward greater transparency, these measures stand out in their recognition of how government regulators must acquire information from industry. While transparency has important virtues, some level of informality and confidentiality is also needed if government is to preserve its ability to play the information game effectively.

${ }^{204}$ Critical Mass Energy Project v. Nuclear Regulatory Commission, 975 F. 2d 871, 878 (D.C. Cir. 1992) (en banc) (finding that disclosure under FOIA of voluntarily disclosed business information "would frustrate Congress's purpose of 'encouraging cooperation with the Government by persons having information useful to officials'”) (quoting National Parks and Conservation Association v. Morton, 498 F. 2d 765 (D.C. Cir. 1974)).

${ }^{205}$ Critical Infrastructure Act of 2001, § 5(a)(1)(A); Homeland Security Act of 2002, § 724.

${ }^{206}$ In addition, there lies lurking behind the Supreme Court litigation involving Vice President Cheney’s energy task force a policy dispute over the balance between transparency and governmental effectiveness. Richard B. Cheney v. U.S. District Court for the District of Columbia, United States Supreme Court, No. 03-475. In response to the Vice President's argument that discovery of executive branch communications would inhibit candid and effective advice to the President, amici favoring disclosure have argued that "representative democracy can succeed only if information about government is broadly available” and that "secrecy is antithetical to representative government.” Brief Amicus Curiae American Library Association, Cheney v. U.S. District Court, No. 03-475 (March 11, 2004). 
Despite noting this, we recognize that informal relationships between regulators and industry may well bring problems, and that transparency offers important virtues. Indeed, our analysis of the information game leads us to call attention to an important but frequently overlooked tradeoff facing administrative law. The challenge is to minimize the sum of two competing types of errors: (1) those associated with agency bias and nefarious conduct, and (2) those associated with regulators' failure to secure necessary information. Recognizing the tradeoff involved in addressing these competing errors is an important step. It opens up a major avenue for future research; ultimately it should make it easier to find solutions that minimize the sum of the two error types. ${ }^{207}$ Such solutions may vary across agencies and regulatory problems, but they will involve striking some balance between opacity and transparency.

One kind of balance could be struck by keeping parts of the regulatory process confidential, but only for limited periods. After the period of confidentiality had lapsed (say, after three to five years), agencies would need to release records of their communications with outsiders. Assurance of confidentiality might give sufficient cover to facilitate information exchange, but general awareness of a subsequent release could counteract temptations to abuse secrecy.

\footnotetext{
${ }^{207}$ Scholars have recognized the existence of risk-risk tradeoffs in health and safety regulation. See, e.g., John D. Graham and Jonathan BaERT WiEnER, Risk Versus Risk: TRAdEOFFS IN Protecting HEALTH AND THE ENVIRONMENT (1995). The basic structure of the tradeoff in the information game is the same, only it is between the risk of bias and the risk of ignorance.
} 
Another option is to keep parts of the regulatory process opaque but impose penalties for demonstrably objectionable conduct. ${ }^{208}$ Given that opacity can be expected to lead to informal trading in information, greater care should be taken to avoid coercion or corrupt actions. Thus, auditing for such abuses by senior managers, agency inspector generals, or the General Accounting Office should be in place, along with adequate penalties.

A final approach is to preserve pockets of opacity in a process that demands reasoned explanations, based on an open agency record, for each new regulation. Agency officials can talk secretly with industry to ferret out adverse information; however, information critical to any new regulation still needs to form part of the agency’s public justification. As a result, any leads or information obtained through opaque channels subsequently should be corroborated through more open means, including the possibility of mandated disclosure. Such an approach fits well with the current presumption of the availability of judicial review. As a check on abuse, courts, legislators, and other overseers demand reasoned explanations of agencies’ regulatory decisions. ${ }^{209}$

The tradeoff between protecting against bias and ensuring regulators obtain necessary information means that transparency should not become transcendent in administrative

${ }^{208}$ Cf. supra note 83 and accompanying text.

${ }^{209}$ In Sierra Club v. Costle, Judge Patricia Wald offered a similar argument for the court's decision to permit agencies to engage in ex parte communications during informal rulemaking. 657 F.2d at 400-10. After explaining some of the virtues and vices of informal contacts in rulemaking, she suggested that the vices would be counteracted by the requirement that the "EPA must justify its rulemaking solely on the basis of the record it compiles and makes public.” Id. 
law. Rather, the goal for administrative law lies in balancing between transparency and opacity along the lines of one or more of the alternatives we have outlined.

\section{Conclusion}

Regulators must rely on industry for significant amounts of information they need to craft effective and efficient regulatory policies. However, it is often not in a firm's or an industry's interest to provide that information. By working closely and informally with industry, regulators can identify specific firms or employees whose interests in disclosure might differ from those of their competitors. Regulators can also try to create incentives - rewards and punishments - that might lead some firms to break with the industry's collective silence. Both strategies are easier to pursue when regulators can interact informally with industry in ways that are not transparent to others, including the overall public.

Much attention has been given in recent years to the need for improving the analytical and scientific basis of regulatory policy making. Congress and the executive branch have required regulatory agencies to engage in more careful policy analysis before issuing new rules. While these efforts have merit, the value of regulatory analysis ultimately depends on the quality and reliability of the information on which it is based. The challenge of securing essential information for regulators' decisions is a fundamental one for anyone interested in improving the quality of regulatory decision making.

Meeting this challenge will require resisting any temptation toward enforced total transparency. Transparency combats the dangers of cozy relationships between 
regulators and industry, to be sure, but it also detracts from regulators' abilities to exploit asymmetries of interest across firms and to engage in informal interactions. The challenge for administrative law is therefore to find an optimal level of visibility, balancing the values served by transparency against regulators' need to employ behindthe-scenes measures to obtain information from those they regulate. Striking the right balance will require recognizing that sometimes government best advances the public interest by giving industry rewards in exchange for information or engaging in informal, off-the-record conversations, even though this behavior may appear indistinguishable from the kind of corruption or regulatory capture that administrative law has long sought to prevent. Ensuring that regulators can secure accurate information therefore calls for sophisticated regulatory practices that allow regulators to extract information yet seek to counteract the kind of regulatory capture that has long been properly deplored. 